\title{
PEPPERDINE
}

UNIVERSITY

Pepperdine Law Review

$1-29-2020$

\section{Testing the First Amendment Validity of Laws Banning Sexual Orientation Change Efforts on Minors: What Level of Scrutiny Applies After Becerra and Does a Proportionality Approach Provide a Solution?}

Clay Calvert

Follow this and additional works at: https://digitalcommons.pepperdine.edu/plr

Part of the Civil Rights and Discrimination Commons, First Amendment Commons, and the Law and Gender Commons

\section{Recommended Citation}

Clay Calvert Testing the First Amendment Validity of Laws Banning Sexual Orientation Change Efforts on Minors: What Level of Scrutiny Applies After Becerra and Does a Proportionality Approach Provide a Solution?, 47 Pepp. L. Rev. 1 (2020)

Available at: https://digitalcommons.pepperdine.edu/plr/vol47/iss1/1

This Article is brought to you for free and open access by the Caruso School of Law at Pepperdine Digital Commons. It has been accepted for inclusion in Pepperdine Law Review by an authorized editor of Pepperdine Digital Commons. For more information, please contact bailey.berry@pepperdine.edu. 


\title{
Testing the First Amendment Validity of Laws Banning Sexual Orientation Change Efforts on Minors: What Level of Scrutiny Applies After Becerra and Does a Proportionality Approach Provide a Solution?
}

Clay Calvert*

\begin{abstract}
This Article examines the standard of scrutiny courts should apply when testing the validity of laws banning speech-based sexual orientation change efforts (SOCE) against First Amendment challenges. Justice Clarence Thomas's 2018 opinion for a five-justice conservative majority of the United States Supreme Court in National Institute of Family and Life Advocates v. Becerra casts considerable doubt on whether a level of inquiry less stringent than strict scrutiny applies. The article analyzes how lower courts after Becerra that have reviewed anti-SOCE laws disagree on the issue. And yet, as the Article explains, the Supreme Court refuses to clarify the muddle. First, it declined in April 2019 to disturb a decision by the U.S. Court of Appeals for the Third Circuit that adopted the relatively deferential intermediate scrutiny test to uphold New Jersey's

* Professor \& Brechner Eminent Scholar in Mass Communication and Director of the Marion B. Brechner First Amendment Project at the University of Florida in Gainesville, Fla. B.A., 1987, Communication, Stanford University; J.D. (Order of the Coif), 1991, McGeorge School of Law, University of the Pacific; Ph.D., 1996, Communication, Stanford University. The author thanks University of Florida student Thomas J. Carbone for reviewing a draft of this Article.
\end{abstract}


[Vol. 47: 1, 2019]

anti-SOCE law. The Supreme Court then followed that up in May 2019 by dodging an opportunity to review a Ninth Circuit decision that applied mere rational basis review in upholding California's anti-SOCE statute. Resolving the scrutiny conundrum is imperative, as new anti-SOCE laws are being adopted nationwide. They, in turn, spawn lawsuits necessitating clear guidance from the Supreme Court if lower bodies are to adopt a predictable and consistent methodology. The Article concludes that anti-SOCE statutes provide a propitious opportunity for embracing Justice Stephen Breyer's proportionality approach rather than one of the three traditional standards of scrutiny. 
[Vol. 47: 1, 2019]

\section{TABLE OF CONTENTS}

I. INTRODUCTION 4

II. Pre-BECERRA CASE LAW: SOMETHING LeSS Than Strict

SCRUTINY CONTROLS ... 12

III. The Supreme Court EXamines Professional SPEECH: How

BECERRA CASTS DOUBT ON PICKUP AND KING 21

IV. A Proportionality APPROACH to ANTI-SOCE StATUTES: AN INSTANCE WHERE FLEXIBILITY IS PARAMOUNT ………............................... 30

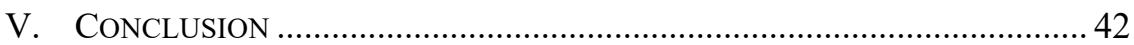


[Vol. 47: 1, 2019]

\section{INTRODUCTION}

In February 2019, United States District Judge Robin Rosenberg in Otto v. City of Boca Raton ${ }^{1}$ addressed a First Amendment ${ }^{2}$ challenge to two ordinances ${ }^{3}$ banning therapists from performing sexual orientation change efforts (SOCE) - also called conversion or reparative therapy ${ }^{4}$ - on minors. ${ }^{5}$ The controversial and contested practice ${ }^{6}$ attempts "to change the sexual orientation, gender identity, or gender expression of LGBT people." It pivots on the premise that homosexuality is a malady to be cured. ${ }^{8}$

1. 353 F. Supp. 3d 1237 (S.D. Fla. 2019)

2. The First Amendment to the U.S. Constitution provides, in relevant part, that "Congress shall make no law ... abridging the freedom of speech, or of the press." U.S. CONST. amend. I. The Free Speech and Free Press Clauses were incorporated nearly ninety-five years ago through the Fourteenth Amendment Due Process Clause as fundamental liberties to apply to state and local government entities and officials. See Gitlow v. New York, 268 U.S. 652, 666 (1925) (finding "that freedom of speech and of the press - which are protected by the First Amendment from abridgment by Congress - are among the fundamental personal rights and 'liberties' protected by the due process clause of the Fourteenth Amendment from impairment by the States").

3. See City of Boca Raton, Fla., Code OF ORdinances ch. 9, art. VI, § 9-106 (2019) ("It shall be unlawful for any provider to practice conversion therapy on any individual who is a minor regardless of whether the provider receives monetary compensation in exchange for such services."); PALM BEACH COUNTY, FLA., CODE OF ORDINANCES ch. 18, art. V, § 18-125 (2019) ("It shall be unlawful for any Provider to engage in conversion therapy on any minor regardless of whether the Provider receives monetary compensation in exchange for such services.").

4. See Caitlin Ryan et al., Parent-Initiated Sexual Orientation Change Efforts with LGBT Adolescents: Implications for Young Adult Mental Health and Adjustment, J. HoMOSEXUALITY 1, (Nov. 7, 2018), https://doi.org/10.1080/00918369.2018.1538407 (noting that efforts to change sexual orientation are "often referred to as 'conversion' or 'reparative' therapy").

5. See Otto, 353 F. Supp. 3d at 1241 ("At its core, this case is about whether Defendants can prohibit the licensed therapists from administering SOCE therapy to minors where the available medical and subject matter literature concludes that the therapy is harmful to minors.").

6. See Annesa Flentje et al., Experiences of Ex-Ex-Gay Individuals in Sexual Reorientation Therapy: Reasons for Seeking Treatment, Perceived Helpfulness and Harmfulness of Treatment, and PostTreatment Identification, 61 J. HOMOSEXUALITY 1242, 1243 (2014) ("Position papers on reorientation therapy from major mental health organizations clearly object to its use.").

7. Press Release, Williams Inst., UCLA Sch. of Law, More than 20,000 LGBT Teens in the US Will be Subjected to Conversion Therapy (Jan. 24, 2018), https://williamsinstitute.law.ucla.edu/press/conversion-therapy-release/.

8. Ignatius Yordan Nugraha, The Compatibility of Sexual Orientation Change Efforts With International Human Rights Law, 35 NETH. Q. HUM. RTS. 176, 179 (2017) ("SOCE are grounded on the belief that homosexuality is an illness or disorder that needs to be cured . ...”). Indeed, it has been 
The fact that anti-SOCE laws like those enacted by Boca Raton and Palm Beach County, Florida - the ordinances at issue in Otto - are proliferating today ${ }^{9}$ is unsurprising. That is largely because an American Psychological Association (APA) task force concluded a decade ago that SOCE "are unlikely to be successful and involve some risk of harm."10 Harms include anxiety, depression, and suicidal feelings. ${ }^{11}$

Multiple studies, in turn, demonstrate "[t]he inefficacy of SOCE."12 Conversion therapy today is "discredited by major medical associations because

observed that conversion therapy rests its alleged value in two false claims about homosexuality: (1) that it is a disorder; and (2) that it can be changed. Peter R. Dubrowski, The Ferguson v. Jonah Verdict and a Path Towards National Cessation of Gay-to-Straight “Conversion Therapy", 110 NW. U. L. REV. ONLINE 77, 80 (2015).

9. By December 2018, fourteen states and the District of Columbia, along with at least forty local governmental entities, had banned SOCE on minors. See Press Release, Williams Inst., UCLA Sch. of Law, 1,000 LGBT Youth Protected from Conversion Therapy in 2018 (Dec. 27, 2018) https://williamsinstitute.law.ucla.edu/press-releases/1000-lgbt-youth-protected-from-conversion-therapy-in2018/ ("To date, 14 states and the District of Columbia as well as 40 localities have banned health care professionals from using conversion therapy on youth."). In January 2019, after addressing similar measures for more than fifteen years, New York became the fifteenth state to ban SOCE on minors. See Michael Gold, New York Passes a Ban on 'Conversion' Therapy After Years-Long Efforts, N.Y. TIMES (Jan. 21, 2019), https://www.nytimes.com/2019/01/21/nyregion/conversion-therapy-ban.html. Then, in April 2019, Massachusetts became the sixteenth state to prohibit it on minors. See Danny McDonald \& Matt Stout, Charlie Baker Signs Bill Banning Gay Conversion Therapy for Minors, Bos. GLOBE, (Apr. 8, 2019, 9:36 PM), https://www.bostonglobe.com/metro/2019/04/08/baker-signs-billbanning-called-gay-conversion-therapy-for-minors/JULbGj7URc3BHnAlK1OMrO/story.html; see also Raisa Habersham, Atlanta Mayor Urges State to Ban LGBTQ Conversion Therapy, ATLANTA J.CONST., (Apr. 16, 2019), https://www.ajc.com/news/local/atlanta-mayor-urges-state-ban-lgbtq-conversion-therapy/EhNPuTTDymzVLnHFvjd1CJ/ ("The practice is already banned in 16 states, the most recent being Massachusetts and New York, and has been long criticized by professional organizations, including the American Psychology Association and American Medical Association, as an attempt to classify homosexuality as a mental disorder.").

10. Am. Psychol. Ass'n, RePORT OF THE AMERICAN PSYCHOlOGICAL ASSOCIATION TASK ForCE on Appropriate Therapeutic Responses to SEXuAl Orientation, at v (2009), https://www.apa.org/pi/lgbt/resources/therapeutic-response.pdf.

11. See Jack Drescher, Can Sexual Orientation Be Changed?, 19 J. GAY \& LeSBIAN Mental HEALTH 84, 89-90 (2015) (“After 'treatment' fails, patients may feel worse and blame themselves, question their faith or their motivation. This may lead to worsening of depression, the onset of anxiety, and possible feelings of suicide.").

12. Jo Fjelstrom, Sexual Orientation Change Efforts and the Search for Authenticity, 60 J. HOMOSEXUALITY 801, 802 (2013). 
it is not scientifically sound." 13 As New York Governor Andrew Cuomo bluntly asserted in January 2019, upon signing legislation that made his state the fifteenth to ban SOCE on minors, conversion therapy is a "fraudulent practice." 14

What is decidedly less clear, however, than the myriad problems with SOCE, is the level of scrutiny to which bans on SOCE with minors are subject when the treatment involves only speech and the therapists performing it claim their First Amendment rights are violated. ${ }^{15}$ As Judge Rosenberg summed up the confusion when trying to determine if strict, ${ }^{16}$ intermediate, ${ }^{17}$

13. Erica Evans \& Emily Hoeven, Will Utah be 16th State to Ban Conversion Therapy?, DESERET NEws (Salt Lake City, Utah) (Feb. 20, 2019, 2:21 PM), https://www.deseretnews.com/article/900056650/will-utah-be-the-16th-state-to-ban-conversion-therapy-for-gay-teens.html. For instance, the American Academy of Child and Adolescent Psychiatry ("AACAP") issued a policy statement in February 2018 finding:

The [AACAP] finds no evidence to support the application of any "therapeutic intervention" operating under the premise that a specific sexual orientation, gender identity, and/or gender expression is pathological. Furthermore, based on the scientific evidence, the AACAP asserts that such "conversion therapies" (or other interventions imposed with the intent of promoting a particular sexual orientation and/or gender as a preferred outcome) lack scientific credibility and clinical utility. Additionally, there is evidence that such interventions are harmful. As a result, "conversion therapies" should not be part of any behavioral health treatment of children and adolescents.

Policy Statement: Conversion Therapy, AM. ACAD. OF CHILD \& ADOLESCENT PSYCHIATRY (Feb. 2018), https://www.aacap.org/aacap/policy_statements/2018/Conversion_Therapy.aspx/.

14. Press Release, Andrew M. Cuomo, Governor, New York State, Governor Cuomo Signs Landmark Legislation Protecting LGBTQ Rights (Jan. 25, 2019), https://www.governor.ny.gov/news/governor-cuomo-signs-landmark-legislation-protecting-lgbtq-rights.

15. See Otto v. City of Boca Raton, 353 F. Supp. 3d 1237, 1242 (S.D. Fla. 2019) ("[T]he law is unsettled as to which of these standards should apply ....").

16. Strict scrutiny generally "applies either when a law is content based on its face or when the purpose and justification for the law are content based." Reed v. Town of Gilbert, 135 S. Ct. 2218, 2228 (2015). Under this test, laws are permissible "only if the government proves that they are narrowly tailored to serve compelling state interests." $I d$. at 2226. Narrow tailoring under this test mandates that a statute "be the least restrictive means" of serving the government's allegedly compelling interest. McCullen v. Coakley, 573 U.S. 464, 478 (2014). See Brown v. Entm’t Merchs. Ass'n, 564 U.S. 786, 799 (2011) (observing that a statute that restricts "the content of protected speech" will pass strict scrutiny only if "it is justified by a compelling government interest and is narrowly drawn to serve that interest"); see also Leslie Kendrick, Content Discrimination Revisited, 98 VA. L. REV. 231, 237 (2012) (“Content-based laws receive strict scrutiny, which nearly always proves fatal.”).

17. Intermediate scrutiny requires the government demonstrate that a significant interest is served by a narrowly tailored statute that does not burden substantially more speech than is necessary to 
or rational basis ${ }^{18}$ scrutiny provided the appropriate test in Otto, "the law is unsettled as to which of these standards should apply to the facts of this case"19 and "the landscape of relevant First Amendment precedent is a morass." 20

In ferreting out the correct standard, Judge Rosenberg noted that the two ordinances appeared on their face to be content-based regulations of speech, ${ }^{21}$ thereby presumptively triggering strict scrutiny. ${ }^{22}$ But she also pointed to

advance that interest. Packingham v. North Carolina, 137 S. Ct. 1730, 1736 (2017) (citing McCullen, 573 U.S. at 486). Intermediate scrutiny typically applies when a law is content-neutral. See Turner Broad. Sys. v. FCC, 512 U.S. 622, 642 (1994) (noting that "regulations that are unrelated to the content of speech are subject to an intermediate level of scrutiny"); see also Minch Minchin, A Doctrine at Risk: Content Neutrality in a Post-Reed Landscape, 22 COMM. L. \& POL'Y 123, 127 (2017) (observing that the Supreme Court "applies intermediate scrutiny for content-neutral laws"). A law is contentneutral when it restricts "communication without regard to the message conveyed." Geoffrey Stone, Restrictions of Speech Because of its Content: The Peculiar Case of Subject-Matter Restrictions, 46 U. CHI. L. REV. 81, 81 (1978).

18. A court will declare a law unconstitutional under rational basis review "if it is not rationally related to a legitimate governmental interest." Thomas B. Nachbar, Rational Basis "Plus", 32 ConsT. Comment. 449, 449 (2017); cf. James M. McGoldrick, Jr., The Rational Basis Test and Why It Is So Irrational: An Eighty-Year Retrospective, 55 SAN DIEGO L. REV. 751, 752-54 (2018) (noting that rational basis "is such a permissive level of review that it is effectively not judicial review at all. It permits the most irrational of legislation to become the law of the land, no matter how needless, wasteful, unwise, or improvident it might be"); Stacey L. Sobel, The Tsunami of Legal Uncertainty: What's a Court to Do Post-McDonald?, 21 CORnELl J. L. \& PUB. POL'Y 489, 495 (2012) ("The lowest level of review is the rational basis test - a highly deferential form of scrutiny. In order for a regulation to survive rational basis review, the challenger must prove that the regulation does not bear a 'rational relationship' to a 'legitimate governmental purpose."')

19. Otto, 353 F. Supp. 3d at 1242.

20. Id. at 1249 .

21. On this point, Judge Rosenberg referenced the U.S. Supreme Court's opinion in Reed, reasoning that:

Reed would seem to compel the conclusion that if the ordinances are content-based, they are subject to strict scrutiny. The ordinances identify certain speech-speech aimed at changing minor patients' sexual orientation-for prohibition because the speech constitutes conversion therapy. The ordinances target what Plaintiffs say to their minor patients. Id. at 1253

22. See id. at 1270 ("The ordinances also seem to regulate on the basis of their content, which would compel strict scrutiny under Reed."). The U.S. Supreme Court has made it clear: "A law that is content based on its face is subject to strict scrutiny regardless of the government's benign motive, content-neutral justification, or lack of 'animus toward the ideas contained' in the regulated speech." Reed v. Town of Gilbert, 135 S. Ct. 2218, 2228 (2015). There is, in fact, a "long-standing practice that a content-based law should be subjected to strict scrutiny." Dan V. Kozlowski \& Derigan Silver, Measuring Reed's Reach: Content Discrimination in the U.S. Circuit Courts of Appeals After Reed v. 
"several lines of cases that exempt content-based laws from automatically being considered under strict scrutiny," ${ }^{23}$ including laws targeting truthful commercial speech ${ }^{24}$ which are subject to intermediate scrutiny. ${ }^{25}$

Judge Rosenberg expressed her belief that "applying intermediate scrutiny to medical treatments that are effectuated through speech would strike the appropriate balance between recognizing that doctors maintain some freedom of speech within their offices, and acknowledging that treatments may be subject to significant regulation under the government's police powers. ${ }^{26}$ She reasoned that applying intermediate scrutiny to anti-SOCE statutes "is entirely consistent with the historic understandings of the First Amendment and its purpose." ${ }^{27}$

Ultimately, however, despite her personal view that intermediate scrutiny was appropriate, ${ }^{28}$ Judge Rosenberg concluded it was "unclear what standard of review should apply to this case. It seems likely that the ordinances are subject to more than rational basis review, but beyond that determination, it is unclear whether intermediate or strict scrutiny should apply."29 The bottom line for Judge Rosenberg was that the Boca Raton and Palm Beach County

Town of Gilbert, 24 COMM. L. \& POL’Y 191, 191 (2019).

23. Otto, 353 F. Supp. 3d at 1253.

24. The U.S. Supreme Court generally uses a four-prong test for analyzing regulations on commercial speech:

[Courts] must determine whether the expression is protected by the First Amendment. For commercial speech to come within that provision, it at least must concern lawful activity and not be misleading. Next, we ask whether the asserted governmental interest is substantial. If both inquiries yield positive answers, we must determine whether the regulation directly advances the governmental interest asserted, and whether it is not more extensive than is necessary to serve that interest.

Cent. Hudson Gas \& Elec. Corp. v. Pub. Serv. Comm'n of N.Y., 447 U.S. 557, 566 (1980).

25. Otto, 353 F. Supp. 3d at 1253-54; see also Lorillard Tobacco Co. v. Reilly, 533 U.S. 525, 572 (2001) (Thomas, J., concurring in part and concurring in judgment) (describing "the intermediate scrutiny of Central Hudson"); Thomas A. Zelante Jr., Comment, Paper or Plastic: Speech in an Unlikely Place, 48 SETON HALl L. REV. 931, 932 (2018) ("Commercial speech restrictions have traditionally been subject to intermediate scrutiny under Central Hudson Gas and Electric Corp. v. Public Service Commission.").

26. Otto, 353 F. Supp. $3 \mathrm{~d}$ at 1256.

27. Id. at 1257.

28. See supra notes 23-25 and accompanying text (describing Judge Rosenberg's own view).

29. Otto, 353 F. Supp. 3d at 1258. 
ordinances prove "that a strict First Amendment rule will not always work for all cases. ${ }^{30}$ In other words, anti-SOCE laws are not easily pigeonholed into a traditional level of scrutiny and they do not fit snugly within what Justice Stephen Breyer derisively calls a First Amendment "jurisprudence of labels." ${ }^{31}$ Indeed, Part IV of this Article contends that Justice Breyer's more flexible proportionality approach to constitutional issues offers an alternative path forward in anti-SOCE law cases. ${ }^{32}$

Not all judges who consider anti-SOCE ordinances, however, perceive such a morass or muddle involving scrutiny. Just two weeks prior to Judge Rosenberg's ruling in Otto, U.S. Magistrate Judge Amanda Sansone in Vazzo v. City of Tampa ${ }^{33}$ considered a motion to dismiss a similar challenge to an anti-SOCE law in a different Florida city. ${ }^{34}$ In refusing to jettison the First Amendment claim filed by conversion therapy counselors Robert Vazzo and David Pickup, ${ }^{35}$ Sansone noted that the pair alleges they "only use speech when they provide SOCE counseling to minors." ${ }^{36}$ She found they had sufficiently pleaded that Tampa's anti-SOCE ordinance was "a content-based law that fails strict-scrutiny analysis." ${ }^{37}$ In the process, Sansone squarely rejected the city's argument that intermediate scrutiny should govern because the ordinance regulated the speech of professionals. ${ }^{38}$ In rebuffing this contention,

30. Id. at 1254 .

31. Pleasant Grove City v. Summum, 555 U.S. 460, 484 (2009) (Breyer, J., concurring).

32. See infra Part IV.

33. No. 8:17-cv-2896-T-02AAS, 2019 U.S. Dist. LEXIS 35935 (M.D. Fla. Jan. 30, 2019).

34. See TAMPA, Fla., CODE OF ORDINANCES ch. 14, art. X, § 14-312 (2019) ("It shall be unlawful for any provider to practice conversion therapy efforts on any individual who is a minor regardless of whether the provider receives monetary compensation in exchange for such services."); see also TAMPA, FlA., CODE OF ORDINANCES ch. 14, art. X, § 14-311 (2019) (using the terms "conversion therapy" and "reparative therapy" interchangeably to mean, in key part, "any counseling, practice or treatment performed with the goal of changing an individual's sexual orientation or gender identity"). 35. See Vazzo, 2019 U.S. Dist. LEXIS 35935, at*45 (denying the City of Tampa's motion to dismiss the plaintiffs' First Amendment free speech claims).

36. Id. at $* 16$.

37. $I d$. at $* 19$.

38. Id. at *18-19. 
the magistrate cited the U.S. Supreme Court's 2018 ruling in National Institute of Family and Life Advocates v. Becerra ${ }^{39}$ to support her conclusion. ${ }^{40}$ Specifically, Sansone reasoned that the nation's high Court in Becerra spurned the proposition "that professional speech is subject to different standards of review under the First Amendment than other speech." ${ }^{41}$ In March 2019, District Judge William Jung adopted Sansone's position. ${ }^{42}$

In brief, and in just one month, two federal jurists in the same stateJudge Rosenberg in Otto and Magistrate Sansone in Vazzo - saw things very differently on precisely the same issue. ${ }^{43}$ The former believed intermediate scrutiny was appropriate, ${ }^{44}$ but confessed the legal landscape was unsettled as to whether it or strict scrutiny was required..$^{45}$ The latter was emphatic that the Supreme Court's recent ruling in Becerra made it unmistakable that intermediate scrutiny was inapplicable and that, instead, strict scrutiny governed. ${ }^{46}$

Judge Rosenberg in Otto refused to issue an injunction that would have stopped enforcement of the two ordinances at issue in the case. ${ }^{47}$ Her decision is now under review by the U.S. Court of Appeals for the Eleventh Circuit. ${ }^{48}$

\footnotetext{
39. 138 S. Ct. 2361 (2018).

40. Vazzo, 2019 U.S. Dist. LEXIS 35935, at*18.

41. $I d$.

42. Vazzo v. City of Tampa, 8:17-cv-2896-T-02AAS, 2019 U.S. Dist. LEXIS 34804, at*1-2 (M.D. Fla. Mar. 5, 2019).

43. See supra notes 26-31, 33-42 and accompanying text (describing these conflicting views).

44. See supra notes 26-27 and accompanying text.

45. See supra note 29 and accompanying text.

46. Vazzo, 2019 U.S. Dist. LEXIS 35935, at*19 ("[Becerra] holds [that] traditional constitutional
} analyses, including strict-scrutiny analysis, applies to content-based regulations on professional speech."). Magistrate Judge Sansone added that Becerra abrogated the logic of the U.S. Court of Appeals for Third Circuit's ruling in King v. Governor of New Jersey, 767 F.3d 216 (3d Cir. 2014), that intermediate scrutiny applied to a New Jersey anti-SOCE ordinance because it regulated the speech of professional therapists. Vazzo, 2019 U.S. Dist. LEXIS 35935, at*18. Sansone explained that Becerra "explicitly rejected King's holding that professional speech is subject to different standards of review under the First Amendment than other speech." Id.

47. Otto v. City of Boca Raton, 353 F. Supp. 3d 1237, 1273 (S.D. Fla. 2019) (denying the plaintiffs' renewed motion for a preliminary injunction).

48. See Jane Musgrave, Federal Judge Upholds County, Boca Conversion Therapy Bans, PALM BEACH POST (Feb. 15, 2019, 8:40 AM), https://www.palmbeachpost.com/news/20190214/federaljudge-upholds-county-boca-conversion-therapy-bans (reporting that Matthew Staver, an attorney for 
Rosenberg stayed the proceedings in her court until the Eleventh Circuit rules, noting that "threshold questions of First Amendment law ... will inevitably have significant effects on the rest of this case." ${ }^{\prime 9}$ In contrast, Magistrate Sansone in Vazzo refused to dismiss the plaintiffs' First Amendment claims challenging Tampa's anti-SOCE ordinance, allowing that suit to progress at the trial court level. ${ }^{50}$

How did two federal courts in Florida in 2019 become so divided over scrutiny when evaluating anti-SOCE ordinances and what, in turn, might remedy the situation? Those are the dual questions animating this Article. It explores how the Supreme Court's 2018 Becerra decision, with its analysis of professional speech, ${ }^{51}$ thoroughly muddled the issue of scrutiny when addressing whether anti-SOCE ordinances violate the First Amendment speech rights of counselors.

Part II reviews how courts had resolved this issue prior to Becerra. ${ }^{52}$ Next, Part III analyzes the majority opinion in Becerra, illustrating how it impacts scrutiny in cases targeting anti-SOCE laws. ${ }^{53}$ Part IV then turns to the post-Becerra landscape of lawsuits challenging laws banning conversion therapy for minors. ${ }^{54}$ In particular, it argues that Justice Stephen Breyer's long-preferred method of constitutional analysis - proportionality, rather than a more rigid and traditional variant of scrutiny — provides a fitting approach for reviewing such laws. Finally, Part V concludes by calling for the Supreme Court to clarify the situation, given that sixteen states ${ }^{55}$ by May 2019 had

Liberty Counsel that represents the conversion therapists in Otto, "said he appealed Rosenberg's decision to the 11th Circuit Court of Appeals less than an hour after he read it").

49. Otto v. City of Boca Raton, No. 9:18-CV-80771, 2019 U.S. Dist. LEXIS 27730, at*3 (S.D. Fla. Feb. 19, 2019).

50. Vazzo, 2019 U.S. Dist. LEXIS 35935, at *45 (“The City's motion to dismiss to plaintiffs' freedom-of-speech claims under the First Amendment (Count I) should be DENIED.").

51. Professional speech, as Professor Claudia Haupt defines it, "reflects the shared knowledge of professionals belonging to a knowledge community that is communicated from professional to client within the confines of a professional-client relationship." Claudia E. Haupt, Licensing Knowledge, 72 VAND. L. REV. 501, 552 (2019).

52. See infra Part II.

53. See infra Part III.

54. See infra Part IV.

55. See supra note 9 and accompanying text. 
[Vol. 47: 1, 2019]

adopted anti-SOCE statutes and future litigation is inevitable. ${ }^{56}$

\section{Pre-Becerra Case Law: Something Less Than STRICT SCRUTINY CONTROLS}

In 2012, California became the first state to adopt a statute ${ }^{57}$ banning licensed therapists from engaging in SOCE with minors. ${ }^{58}$ California defines SOCE as "any practices by mental health providers that seek to change an individual's sexual orientation. This includes efforts to change behaviors or gender expressions, or to eliminate or reduce sexual or romantic attractions or feelings toward individuals of the same sex. ${ } 59$

The law was challenged by SOCE practitioners on First Amendment speech grounds, but the U.S. Court of Appeals for the Ninth Circuit rejected that attack in a unanimous amended opinion in 2014 in Pickup v. Brown. ${ }^{60}$ The opinion wrestled with an issue at the heart of this Article- whether First Amendment speech interests required the law to be analyzed under "heightened scrutiny." ${ }^{\prime 1}$ In an opinion authored by Judge Susan Graber and joined by Judge Alex Kozinski (then-chief judge of the Ninth Circuit) and Judge Morgan Christen, the appellate court held they did not. ${ }^{62}$

In resolving the scrutiny question, the Ninth Circuit considered whether the anti-SOCE statute regulated speech or conduct and, in the process, the extent to which the First Amendment protects the speech of professionals, including mental healthcare providers. ${ }^{63}$ The former issue is critical due to a

56. See infra Part V.

57. See CAL. BuS. \& Prof. CodE $§ 865.1$ (2013) ("Under no circumstances shall a mental health provider engage in sexual orientation change efforts with a patient under 18 years of age.").

58. See Marie-Amélie George, Expressive Ends: Understanding Conversion Therapy Bans, 68 ALA. L. REV. 793, 795 (2017).

59. CAL. Bus. \& PROF. CODE $\S 865(\mathrm{~b})(1)$ (2019).

60. 740 F.3d 1208 (9th Cir. 2014).

61. Id. at 1225 .

62. Id

63. See id. at 1227 (observing that "we must . . . consider more generally the First Amendment rights of professionals, such as doctors and mental health providers," and adding that, in deciding if California's anti-SOCE law is "a regulation of speech or conduct, we find it helpful to view this issue along a continuum"). 
rudimentary dichotomy in First Amendment jurisprudence between laws regulating speech ${ }^{64}$ and those affecting conduct. ${ }^{65}$ Laws policing only conduct generally are not subject to First Amendment scrutiny, ${ }^{66}$ unless the conduct rises to the level of symbolic expression, ${ }^{67}$ such as burning the flag of the United States of America in political protest. ${ }^{68}$ Although the line demarcating speech and conduct sometimes is unclear, ${ }^{69}$ Justice Clarence Thomas, in penning the majority opinion in Becerra - the case that, as this Article explains in Part II, throws a monkey wrench into the gears of the scrutiny question in anti-SOCE law cases-emphasized that the Court has "long drawn it."

64. See generally Clay Calvert, Fringes of Free Expression: Testing the Meaning of "Speech" Amid Shifting Cultural Mores \& Changing Technologies, 22 S. CAL. INTERDISC. L.J. 545 (2013) (analyzing the meaning of the word "speech" within the First Amendment as used by courts).

65. See Erica Goldberg, Competing Free Speech Values in an Age of Protest, 39 CARDOZO L. REV. 2163, 2204 (2018), for an explanation from Professor Goldberg that:

The divide between pure speech — no matter how objectionable - and conduct is fundamental to preserving First Amendment freedoms. Unless speech imminently threatens violence or imminent lawless action, it cannot be regulated or abridged, whereas the state retains wide latitude to regulate conduct. The distinction between speech and conduct, although difficult to discern at the margins, is not only necessary to operationalize the First Amendment, but it is necessary for a peaceful, "pluralistic" society.

See generally Diahann DaSilva, Playing a "Labeling Game": Classifying Expression as Conduct as a Means of Circumventing First Amendment Analysis, 56 B.C. L. REV. 767, 769-70 (2015) (observing "the speech versus conduct dichotomy," and analyzing the "distinction between speech and conduct, the implications of that distinction, and how courts have classified various activities as speech or conduct"); Paul Sherman, Occupational Speech and the First Amendment, 128 HARV. L. REV. F. 183, 188 (2015) ("The notion that there is a distinction between laws that regulate speech and laws that regulate conduct with merely an incidental effect on speech is well established.").

66. See Barnes v. Glen Theatre, Inc., 501 U.S. 560, 572 (1991) (Scalia, J., concurring) ("[A] general law regulating conduct and not specifically directed at expression . . . is not subject to First Amendment scrutiny at all.").

67. See Virginia v. Black, 538 U.S. 343, 358 (2003) ("The First Amendment affords protection to symbolic or expressive conduct as well as to actual speech.").

68. See Texas v. Johnson, 491 U.S. 397, 406 (1989); see also Wesley J. Campbell, Speech-Facilitating Conduct, 68 STAN. L. REV. 1, 10 (2016) (noting that "[b]urning flags, wearing black armbands, participating in a parade, and even dancing in the nude are well-known examples" of expressive conduct).

69. See Richard Blum, Labor Picketing, the Right to Protest, and the Neoliberal First Amendment, 42 N.Y.U. REV. L. \& SOC. CHANGE 595, 619 (2019) ("It is often exceedingly difficult, if not impossible to distinguish between speech and conduct, since all speech involves some element of conduct.").

70. See Nat'l Inst. of Family \& Life Advocates v. Becerra, 138 S. Ct. 2361, 2373 (2018) ("While drawing the line between speech and conduct can be difficult, this Court's precedents have long drawn 
The Ninth Circuit concluded that the Golden State's anti-SOCE law regulated "professional conduct, where the state's power is great, even though such regulation may have an incidental effect on speech." ${ }^{71}$ This determination was pivotal because it spared the statute from rigorous review, thereby virtually ensuring its constitutionality. In a nifty bit of judicial jujitsu that removed free speech concerns from the equation, the Ninth Circuit reasoned that the law targeted only "treatment," 72 and treatment, in turn, constitutes conduct. $^{73}$ It added that "the fact that speech may be used to carry out those therapies does not turn the regulation of conduct into a regulation of speech." 74 Talk therapy, in other words, is conduct, ${ }^{75}$ and thus it falls on the lowest or weakest point of what the Ninth Circuit dubbed "a continuum" of "the First Amendment rights of professionals, such as doctors and mental health providers." ${ }^{76}$

As for the First Amendment interests, the Ninth Circuit reasoned they were not adversely affected because the conversion therapist plaintiffs remained free to express their opinions about the merits of SOCE and to dispense information about it. ${ }^{77}$ They just could not perform it, and this impact on speech was "merely incidental" to the regulated conduct. ${ }^{78}$ Whether California's anti-SOCE law truly had only an "incidental" effect on speech is ripe for debate, but the Ninth Circuit's framing it as such certainly was strategic.

it.").

71. Pickup v. Brown, 740 F.3d 1208, 1229 (9th Cir. 2014).

72. Id.

73. See id. (observing that the law "regulates conduct. It bans a form of treatment for minors; it does nothing to prevent licensed therapists from discussing the pros and cons of SOCE with their patients").

74. Id.

75. See id. at 1231 ("[T]alk therapy does not receive special First Amendment protection merely because it is administered through speech.").

76. Id. at 1227 .

77. See id. at 1230 ("The statute does not restrain Plaintiffs from imparting information or disseminating opinions; the regulated activities are therapeutic, not symbolic.").

78. Id. at 1231 . 
That is because, as the U.S. Supreme Court observed in 2011 in Sorrell $v$. IMS Health Inc., 79 "the First Amendment does not prevent restrictions directed at commerce or conduct from imposing incidental burdens on speech." ${ }^{\prime 80}$ Indeed, much like the dichotomy addressed earlier between speech and conduct ${ }^{81}$ there is a crucial division in First Amendment jurisprudence separating what Professor Dan Coenen recently called "laws that directly burden speech from laws that burden speech only 'incidentally." "82 Laws falling into the latter category, as Professor Michael Dorf noted more than two decades ago, "trigger more deferential judicial scrutiny." 83

In fact, the Ninth Circuit in Pickup concluded that California's anti-SOCE statute was "subject to only rational basis review and must be upheld if it bears a rational relationship to a legitimate state interest." 84 In other words, neither of the traditional heightened standards of scrutiny in First Amendment lawstrict or intermediate - applied. ${ }^{85}$ The speech interests of the conversion therapists were treated, instead, by the Ninth Circuit on par with those of public high school students under the Supreme Court's ruling in Hazelwood School District v. Kuhlmeier ${ }^{86}$ and prisoners per the Court's decision in Turner v. Safley. ${ }^{87}$

\footnotetext{
79. 564 U.S. 552 (2011).

80. Id. at 567.

81. See supra notes $64-70$ and accompanying text.

82. Dan T. Coenen, Free Speech and Generally Applicable Laws: A New Doctrinal Synthesis, 103 IOWA L. REV. 435, 437 (2018).

83. Michael C. Dorf, Incidental Burdens on Fundamental Rights, 109 HARV. L. REV. 1175, 1178
} (1996).

84. Pickup v. Brown, 740 F.3d 1208, 1231 (9th Cir. 2014).

85. See supra notes $16-17$ and accompanying text (addressing, respectively, strict scrutiny and intermediate scrutiny).

86. 484 U.S. 260 (1988). In Kuhlmeier, the Court held "that educators do not offend the First Amendment by exercising editorial control over the style and content of student speech in schoolsponsored expressive activities so long as their actions are reasonably related to legitimate pedagogical concerns." Id. at 273. Dean Erwin Chemerinsky equates this test to "the classic phrasing of the rational basis review." Erwin Chemerinsky, The Hazelwooding of the First Amendment: The Deference to Authority, 11 FIRST AMEND. L. REV. 291, 294 (2013).

87. 482 U.S. 78 (1987). In Turner, the Court held that "when a prison regulation impinges on inmates' constitutional rights, the regulation is valid if it is reasonably related to legitimate penological interests." Id. at 89. This was recently described as "a low rational basis standard of review" that is "fairly deferential to the state." Jennifer A. Brobst, The Metal Eye: Ethical Regulation of the State's 
Applying rational basis review, the Ninth Circuit had little problem finding that safeguarding minors from harm was a legitimate state interest and that - regardless of whether SOCE actually causes harm - it was reasonably conceivable for California lawmakers to believe that SOCE is harmful. ${ }^{88}$ The appellate court furthermore concluded that lawmakers had acted rationally in adopting the measure because they relied partly ${ }^{89}$ on a report by a task force of the APA described earlier ${ }^{90}$ which found SOCE to be ineffective and harmful. ${ }^{91}$ The law thus passed rational basis review. ${ }^{92}$ Later in 2014, the U.S. Supreme Court declined to disturb that ruling. ${ }^{93}$

The same year that the Ninth Circuit held in Pickup that California's antiSOCE law regulated conduct — not speech — and was subject to rational basis review, the Third Circuit reached a very different conclusion in King v. Governor of New Jersey. ${ }^{94}$ There, the appellate court considered the constitutionality of New Jersey's anti-SOCE statute..$^{95}$ New Jersey was the second state

Use of Surveillance Technology and Artificial Intelligence to Observe Humans in Confinement, 55 CAL. W. L. REV. 1, 49 (2018). Indeed, "[p]risoners seldom prevail when judges apply the Turner test." Christopher E. Smith, Justice Sandra Day O'Connor and Corrections Law, 32 HamLine L. REV. 477, 491 (2009).

88. Pickup, 740 F.3d at 1231 .

89. The Ninth Circuit also noted that California lawmakers rationally relied on reports of other professional organizations - namely, the American School Counselor Association, the American Academy of Pediatrics and the National Association of Social Workers - to support their decision to ban SOCE on minors. Id. at 1232.

90. See supra note 10 and accompanying text.

91. Pickup, 740 F.3d at 1232 .

92. See id. (concluding that California's anti-SOCE law "is rationally related to the legitimate government interest of protecting the well-being of minors").

93. See Pickup v. Brown, 573 U.S. 945 (2014) (denying the petition for a writ of certiorari).

94. 767 F.3d 216 (3d Cir. 2014).

95. N.J. REV. STAT. § 45:1-55(a) (2019) (providing, in key part, that individuals "licensed to provide professional counseling . . . shall not engage in sexual orientation change efforts with a person under 18 years of age."). The New Jersey statute defines SOCE as "the practice of seeking to change a person's sexual orientation, including, but not limited to, efforts to change behaviors, gender identity, or gender expressions, or to reduce or eliminate sexual or romantic attractions or feelings toward a person of the same gender." N.J. STAT. § 45:1-55(b) (2019). The New Jersey law exempts from its definition of SOCE counseling designed to facilitate gender transitioning, as well as "counseling that (1) provides acceptance, support, and understanding of a person or facilitates a person's coping, social support, and identity exploration and development, including sexual orientation-neutral interventions to prevent or address unlawful conduct or unsafe sexual practices; and (2) does not seek to change 
to adopt an anti-SOCE statute. ${ }^{96}$

Initially, the Third Circuit parted ways with the Ninth Circuit by concluding that "the verbal communication that occurs during SOCE counseling is speech that enjoys some degree of protection under the First Amendment." 97 In other words, the anti-SOCE law did not simply regulate conduct and only incidentally affect speech, as the Ninth Circuit had found when considering California's similar statute. ${ }^{98}$

Second, the Third Circuit distanced itself from the Ninth by applying a heightened level of inquiry rather than mere rational basis review. ${ }^{99}$ In particular, it embraced a version of intermediate scrutiny ${ }^{100}$ closely tracking the one adopted by the Supreme Court in Central Hudson Gas \& Electric Corp. v. Public Service Commission ${ }^{101}$ for analyzing laws restricting truthful and nonmisleading commercial speech. ${ }^{102}$ The Third Circuit reasoned that New Jersey's anti-SOCE law would pass First Amendment muster "if it 'directly advances' the government's interest in protecting clients from ineffective and/or harmful professional services, and is 'not more extensive than necessary to serve that interest." $" 103$

sexual orientation." Id.

96. See Press Release, Garden State Equality, U.S. Supreme Court Declines to Hear Challenge Against New Jersey's LGBTQ Conversion Therapy Ban (Apr. 15, 2019), https://www.gardenstateequality.org/scotus_rejects ("The ban was signed into law in August 2013 by former Governor Chris Christie, a Republican, after being approved by both houses of the state legislature with a vetoproof supermajority. New Jersey was the second state in the nation to pass a ban on conversion therapy for minors.")

97. King, 767 F.3d at 224.

98. See supra notes 71-78 and accompanying text (addressing these aspects of the Ninth Circuit's ruling in Pickup).

99. King, 767 F.3d at 234.

100. Id.

101. 447 U.S. 557 (1980); see supra notes 24-25 (setting forth the Central Hudson test for commercial speech and noting that it commonly is referred to as an intermediate level of scrutiny).

102. King, 767 F.3d at 234 ("We believe that commercial and professional speech share important qualities and, thus, that intermediate scrutiny is the appropriate standard of review for prohibitions aimed at either category.").

103. Id. at 237 (quoting Cent. Hudson Gas \& Elec. Corp., 447 U.S. at 566). 
[Vol. 47: 1, 2019]

Applying this test, the Third Circuit concluded the law was constitutional. ${ }^{104}$ In particular, it found that New Jersey had:

- an "unquestionably substantial" interest in "protecting its citizens from harmful professional practices" and an "even stronger" interest in King because minors needed protection, ${ }^{105}$

- "substantial" 106 proof, albeit not necessarily "conclusive scientific evidence," 107 regarding the serious harms wrought by SOCE, as well as the inefficacy of SOCE, to support the idea that the statute directly advanced the state's interest in protecting minors; ${ }^{108}$ and

- adopted a measure that was "sufficiently tailored to survive intermediate scrutiny" 109 because the law's challengers failed to prove that less speech-restrictive means of protecting minors, such as requiring their informed consent before undergoing SOCE, would actually prove effective in doing so. ${ }^{110}$

Just as the Ninth Circuit noted that California's statute did not stop SOCE counselors from dispensing information about SOCE or giving their opinions regarding its merits, ${ }^{111}$ the Third Circuit observed that New Jersey's law "does not prevent these counselors from engaging in a public dialogue on homosexuality or sexual orientation change." 112 In other words, both appellate courts made light of the fact that the laws did not thwart SOCE counselors from publicly advocating for it in a way that might someday cause a legislative body to

\footnotetext{
104. Id. at 240 .

105. Id. at 237.

106. Id. at 238 .

107. Id. at 239.

108. Id.

109. Id. at 240 .

110. Id. (explaining that minors might consent to SOCE counseling and treatment, despite fear of harm, because of pressure from family members or their community).

111. See supra note 77 and accompanying text.

112. King, 767 F.3d at 233.
} 
repeal an anti-SOCE law. ${ }^{113}$ In brief, the speech-based remedy for SOCE counselors runs through the legislative process - to convince anti-SOCE lawmakers to change their minds about conversion therapy or to persuade the citizens who supported those lawmakers to vote them out of office - not a courtroom. ${ }^{114}$

Why, however, wasn't New Jersey's anti-SOCE law subject to strict scrutiny, ${ }^{115}$ a more rigorous level of heightened review than intermediate scrutiny? ${ }^{116}$ After all, the Third Circuit in King readily acknowledged both that New Jersey's anti-SOCE statute was a content-based regulation of speech ${ }^{117}$ and that such regulations generally face strict scrutiny. ${ }^{118}$

Here, the Third Circuit reasoned that the anti-SOCE law regulated the speech of professionals ${ }^{119}$ and, in turn, that such expression "warrants lesser protection" 120 when a professional is providing "personalized services to a client based on the professional's expert knowledge."121 The justification for such reduced protection for professional speech, the Third Circuit reasoned, is largely twofold:

(1) a distinct power imbalance between professionals and their clients regarding information and knowledge - an imbalance putting clients

113. See generally Ian Moss, Ending Reparative Therapy in Minors: An Appropriate Legislative Response, 52 FAM. CT. REV. 316, 321 (2014) (clarifying that the California and New Jersey SOCE "bans do not criminalize forms of speech or religious belief, but merely clarif[y] what is and is not acceptable practice for mental health practitioners licensed by the state").

114. See Moss, supra note 113, at 320 (applauding California and New Jersey's state legislatures for enacting necessary legislation to protect minors).

115. See supra note 16 (describing strict scrutiny).

116. See supra note 17 (describing intermediate scrutiny).

117. See King, 767 F.3d at 236 (concluding that the law "discriminates on the basis of content").

118. See id. ("Ordinarily, content-based regulations are highly disfavored and subjected to strict scrutiny. And this is generally true even when the law in question regulates unprotected or lesser protected speech." (citation omitted)).

119. See id. at 233 (concluding "that speech occurring as part of SOCE counseling is professional speech").

120. Id. at 232 .

121. Id. 
at a disadvantage that requires them to place their trust in professionals; $;{ }^{122}$ and

(2) the historically close regulation of professionals by the government. ${ }^{123}$

Thus, just as commercial speech is given second-class status in the hierarchy of First Amendment speech varieties and therefore is more easily regulated, ${ }^{124}$ so too is professional speech. ${ }^{125}$

In summary, while both the Ninth and Third Circuit upheld anti-SOCE statutes in 2014, they did so under different standards of judicial reviewrational basis in Pickup in the Ninth Circuit ${ }^{126}$ and intermediate scrutiny in King in the Third Circuit. ${ }^{27}$ Furthermore, the two appellate courts differed over whether speech was even at issue - the Ninth Circuit concluded it was not, ${ }^{128}$ the Third Circuit determined it was. ${ }^{129}$ Where the two courts agreed, however, was that strict scrutiny was inapplicable and that the speech of professionals that occurs during the scope of a professional-client relationship

\footnotetext{
122. On this point, the Third Circuit explained that:

Licensed professionals, through their education and training, have access to a corpus of specialized knowledge that their clients usually do not. Indeed, the value of the professional's services stems largely from her ability to apply this specialized knowledge to a client's individual circumstances. Thus, clients ordinarily have no choice but to place their Id. trust in these professionals, and, by extension, in the State that licenses them.
}

123. See id. at 229, 234 ("The authority of the States to regulate the practice of certain professions is deeply rooted in our nation's jurisprudence. . . . States have traditionally enjoyed broad authority to regulate professions as a means of protecting the public from harmful or ineffective professional services.").

124. See Jed Rubenfeld, The First Amendment's Purpose, 53 Stan. L. REV. 767, 830 (2001) (writing that commercial speech currently is "treated as a second-class First Amendment citizen").

125. See Pickup v. Brown, 740 F.3d 1208, 1227-28 (9th Cir. 2014) (reasoning that First Amendment speech should be viewed as a continuum, and "[a]t the midpoint of the continuum, within the confines of a professional relationship, First Amendment protection of a professional's speech is somewhat diminished").

126. See supra note 84 and accompanying text.

127. See supra note 100 and accompanying text.

128. See supra note 71 and accompanying text (concluding that only conduct was at issue).

129. See supra note $97-98$ and accompanying text. 
[Vol. 47: 1, 2019]

may be regulated more closely than — and thus is not subject to the same First Amendment rules as - speech arising in other settings. ${ }^{130}$

It was into this split-of-authority over scrutiny that the U.S. Supreme Court waded - albeit indirectly - in 2018 in National Institute of Family and Life Advocates v. Becerra. ${ }^{131}$ How that decision affects anti-SOCE law litigation is the focus of the next Part of this Article.

\section{The Supreme Court Examines Professional SpeEch: How BECERRA CASTS DOUBT ON PICKUP AND KING}

In Becerra, a five-Justice majority comprised of the Supreme Court's conservative-leaning Justices ${ }^{132}$ held that two provisions ${ }^{133}$ of a California law ${ }^{134}$ that compelled anti-abortion crisis pregnancy centers ${ }^{135}$ to convey factual messages they disagreed with likely violated ${ }^{136}$ those centers' unenumerated First Amendment right not to speak. ${ }^{137}$ The right not to be forced to speak

130. See King v. Governor of N.J., 767 F.3d 216, 232 (3d Cir. 2014) (concluding "that a licensed professional does not enjoy the full protection of the First Amendment when speaking as part of the practice of her profession"); Pickup, 740 F.3d at 1228 ("[T] amount of speech regulation within the professional-client relationship that it would not tolerate outside of it.").

131. 138 S. Ct. 2361 (2018).

132. Justice Clarence Thomas penned the majority opinion, which was joined by Chief Justice John Roberts and Justices Anthony Kennedy, Samuel Alito, and Neil Gorsuch. Becerra, 138 S. Ct. at 2367.

133. Licensed crisis pregnancy centers were required to inform patients that California provides "immediate free or low-cost access" to abortion services to financially eligible women. CAL. HEALTH \& SAFETY CODE $\S 123472(a)(1)$ (West 2016). Unlicensed centers had to notify patients that they were not licensed by California to provide medical services. HEALTH \& SAFETY CODE $\S 123472(\mathrm{~b})(1)$.

134. The provisions were part of the Reproductive Freedom, Accountability, Comprehensive Care, and Transparency Act ("FACT"). HEALTH \& SAFETY CODE $§ 123470$.

135. See Becerra, $138 \mathrm{~S}$. Ct. at 2371 (noting that the petitioners, who operate the centers, "are devoted to opposing" abortion).

136. See id. at 2378 ("We hold that petitioners are likely to succeed on the merits of their claim that the FACT Act violates the First Amendment.").

137. See generally Abner S. Greene, "Not in My Name" Claims of Constitutional Right, 98 B.U. L. REV. 1475, 1486 (2018) (observing that the Supreme Court "has interpreted the First Amendment as offering robust protection for a right not to speak"); Diala Shamas, A Nation of Informants: Reining in Post-9/11 Coercion of Intelligence Informants, 83 BROOK. L. REV. 1175, 1204 (2018) ("The First Amendment protects against compelled speech or compelled association; in other words, it protects 
by the government is firmly entrenched in First Amendment jurisprudence. ${ }^{138}$ As one scholar notes, "The Supreme Court has repeatedly held that the right of free speech includes the right not to be compelled to speak." ${ }^{139}$ In fact, the day after the Court ruled in Becerra, the same bloc of conservative Justices observed in Janus v. American Federation of State, County and Municipal Employees $^{140}$ that "measures compelling speech are at least as threatening"141 as those restricting it.

Of particular importance for this Article, however, is not the scope of the doctrine against compelled speech; rather, it is the part of the Becerra majority opinion, authored by Justice Clarence Thomas, that addresses professional speech. ${ }^{142}$ As described in Part II, both the Ninth Circuit in Pickup and the Third Circuit in King contended that professional speech could be regulated more easily than other types of expression, thereby greasing the legal skids for applying a test less rigorous than strict scrutiny when analyzing anti-SOCE statutes. ${ }^{143}$

The issue of professional speech arose in Becerra because the Ninth Circuit had upheld the compelled-speech obligation imposed on licensed crisis pregnancy centers by analyzing its constitutionality under intermediate-rather than strict-scrutiny. ${ }^{144}$ The Ninth Circuit reasoned that although the mandate requiring licensed centers to inform women that California offered free and low-cost abortion services was content based, ${ }^{145}$ strict scrutiny was

the right not to speak and not to associate."); Mark A. Strasser, What's Fair for Conscientious Objectors Subject to Public Accommodations Laws, 48 N.M. L. REV. 124, 125 (2018) (noting that the Supreme Court takes the right not to speak "seriously and affords it constitutional protection").

138. See, e.g., Richard F. Duncan, A Piece of Cake or Religious Expression: Masterpiece Cakeshop and the First Amendment, 10 NEB. L. REV. BULL. 1 (2019).

139. See Duncan, supra note 138, at 5.

140. 138 S. Ct. 2448 (2018).

141. Id. at 2464.

142. See Nat'1 Inst. Of Family \& Life Advocates v. Becerra, 138 S. Ct. 2361, 2371-76 (2018).

143. See supra Part II.

144. See Nat'l. Inst. of Family \& Life Advocates v. Harris, 839 F.3d 823, 829 (9th Cir. 2016), rev'd sub nom., Becerra, 138 S. Ct. 2361 ("For the free speech claim, we conclude that the proper level of scrutiny to apply to the Act's regulation of licensed clinics is intermediate scrutiny, which it survives.").

145. See id. at 834 (finding that the law at issue "is a content-based regulation"). 
inapplicable because the law regulated professional speech. ${ }^{146}$ Professional speech regulations in this context, the Ninth Circuit held, were subject to only intermediate scrutiny. ${ }^{147}$ In reaching this conclusion, the appellate court relied heavily on its ruling in the anti-SOCE case of Pickup. ${ }^{148}$

In applying intermediate scrutiny to the speech-mandate imposed on licensed crisis pregnancy centers, the Ninth Circuit found that California had "a substantial interest in the health of its citizens, including ensuring that its citizens have access to and adequate information about constitutionally-protected medical services like abortion." ${ }^{149}$ The court also determined the obligation was narrowly tailored because the required disclosure - that California offered free and low-cost abortion services to eligible women ${ }^{150}$ - "informs the reader only of the existence of publicly-funded family-planning services. It does not contain any more speech than necessary, nor does it encourage, suggest, or imply that women should use those state-funded services." ${ }^{151}$ The law affecting licensed centers thus survived intermediate scrutiny, which the Ninth Circuit deemed applicable to professional speech. ${ }^{152}$

Justice Clarence Thomas and the Becerra majority, however, pushed back forcefully against the view that professional speech constitutes a special category of expression - one with its own set of rules - in First Amendment jurisprudence. ${ }^{153}$ Thomas wrote that "neither California nor the Ninth Circuit has identified a persuasive reason for treating professional speech as a unique category that is exempt from ordinary First Amendment principles." ${ }^{154}$ Thomas

\footnotetext{
146. Id.

147. Id.

148. See id. at $838-40$.

149. Id. at 841.

150. See CAL. HeAlth \& SAFETy CODE $§ 123472$ (a)(1) (West 2016) (requiring licensed crisis pregnancy centers to inform women that "California has public programs that provide immediate free or low-cost access to comprehensive family planning services (including all FDA-approved methods of contraception), prenatal care, and abortion for eligible women").

151. Harris, 839 F.3d at 842 .

152. See id. at 844 ("The Licensed Notice regulates professional speech, subject to intermediate scrutiny, which it survives.").

153. See Nat'l Inst. of Family \& Life Advocates v. Becerra, 138 S. Ct. 2361, 2372 (2018) ("This Court's precedents do not recognize such a tradition for a category called 'professional speech."').

154. Id. at 2375 .
} 
opined there were only two situations when professionals receive less First Amendment protection than would be expected for other individuals or entities. ${ }^{155}$ Those exceptions, which Thomas stressed do not hinge "on the fact that professionals [are] speaking," ${ }^{\prime 156}$ arise: (1) when professionals advertise their services; ${ }^{157}$ and (2) when laws targeting professionals' conduct incidentally affect their speech. ${ }^{158}$

In support of the former exception, Thomas cited the Court's 1985 ruling in the attorney-advertising case of Zauderer v. Office of Disciplinary Counsel of Supreme Court of Ohio. ${ }^{159}$ For Thomas and the Becerra majority, Zauderer stands for the principle that laws compelling professionals to reveal uncontroversial facts about the terms under which they provide services to clients are permissible, provided the disclosure mandate is not unduly burdensome. ${ }^{160}$ Put slightly differently, states may, under narrow circumstances, require professionals to convey factual content in advertisements without triggering heightened scrutiny. ${ }^{161}$

In support of the latter exception regarding incidental effects on speech caused by laws regulating professionals' conduct, ${ }^{162}$ Thomas leaned heavily

155. Id. at 2372 .

156. Id.

157. See id. ("First, our precedents have applied more deferential review to some laws that require professionals to disclose factual, noncontroversial information in their "commercial speech.").

158. See id. ("Second, under our precedents, States may regulate professional conduct, even though that conduct incidentally involves speech.").

159. 471 U.S. 626 (1985).

160. Becerra, 138 S. Ct. at 2372. The Court in Zauderer held that a state may compel an attorney "in his advertising [to convey] purely factual and uncontroversial information about the terms under which his services will be available," provided that the facts disclosed "are reasonably related to the State's interest in preventing deception of consumers" and the mandate is not "unduly burdensome." Zauderer, 471 U.S. at 651.

161. Zauderer, 471 U.S. at 651 . The Zauderer test typically is described as being similar to rational basis review. See Lili Levi, A "Faustian Pact"? Native Advertising and the Future of the Press, 57 ARIZ. L. REV. 647, 681 (2015) (observing that the test in Zauderer is "akin to rational basis review"); Shannon M. Roesler, Evaluating Corporate Speech About Science, 106 GEO. L.J. 447, 505 ("Many courts and commentators have treated the Zauderer 'reasonable relationship' test as a highly deferential test similar to rational basis review.").

162. See Becerra, 138 S. Ct. at 2373 (noting that "this Court has upheld regulations of professional conduct that incidentally burden speech"). 
on the Court's rulings in Sorrell v. IMS Health Inc. ${ }^{163}$ and Planned Parenthood of Southeastern Pennsylvania v. Casey. ${ }^{164}$ Casey, the majority found, supported the proposition that informed-consent requirements that require professionals - in Casey, doctors who perform abortions - to disclose certain facts about a procedure are permissible because they only regulate speech within the context of administering treatment. ${ }^{165}$

Of vital importance for whether something less than strict scrutiny suffices when challenging anti-SOCE statutes, the Becerra majority observed that both the Third Circuit in King and the Ninth Circuit in Pickup "except professional speech from the rule that content-based regulations of speech are subject to strict scrutiny." 166 The U.S. Supreme Court, however, has never recognized such a carve-out from strict scrutiny for anything labeled professional speech, Thomas flatly asserted. ${ }^{167}$ The only situations when contentbased rules affecting professionals' speech are subject to deferential review,

163. 564 U.S. 552 (2011). In Sorrell, a divided Court declared unconstitutional a Vermont statute that prohibited: (1) pharmacies from selling data about the prescribing practices of identifiable physicians to anyone who intended to use the data for marketing purposes; and (2) pharmaceutical makers and their sales representatives from using prescriber information in their marketing practices. Id. at $558-59,580$.

The majority held that the law imposed more than just an incidental burden on speech. Id. at 567. It concluded the statute necessitated "heightened judicial scrutiny" because it imposed a burden based on both the content of the speech and the identity of the speaker. Id. at 565-67. The majority, however, acknowledged that "restrictions on protected expression are distinct from restrictions on economic activity or, more generally, on nonexpressive conduct" and "that the First Amendment does not prevent restrictions directed at commerce or conduct from imposing incidental burdens on speech." Id. at 567. The Vermont law, in the majority's opinion, did not fit into those exceptions allowing for deferential review. Id. at 579 .

164. 505 U.S. 833 (1992). In Casey, among other things, the Court upheld an informed-consent requirement in the face of a First Amendment speech challenge by physicians who did not wish to be compelled to disclose certain information to women seeking abortions. Id. at 884 . The Court concluded that the physicians' First Amendment interest in not being compelled to disclose certain risks about abortion arose "only as part of the practice of medicine, subject to reasonable licensing and regulation by the State." Id.

165. Becerra, 138 S. Ct. at 2373.

166. Id. at 2371 .

167. See id. at 2371-72 ("But this Court has not recognized 'professional speech' as a separate category of speech. Speech is not unprotected merely because it is uttered by 'professionals.'”). 
he reasoned, are the two described above: (1) compelled disclosures of noncontroversial facts in advertising; ${ }^{168}$ and (2) conduct regulations incidentally affecting speech, including factual disclosures via informed-consent mandates. ${ }^{169}$

This raises a crucial question: How does Becerra's assault on the professional-speech logic of both Pickup and King impact the level of scrutiny that applies when analyzing anti-SOCE statutes?

The answer, in brief, is that Becerra leaves anti-SOCE law jurisprudence - particularly regarding First Amendment scrutiny-in turmoil. The schism over scrutiny in 2019 between the courts in Otto v. City of Boca Ra$\operatorname{ton}^{170}$ and Vazzo v. City of Tampa ${ }^{171}$ —recall, as well, that Magistrate Sansone in Vazzo cited Becerra in concluding that the plaintiffs successfully pleaded that strict scrutiny was the correct test for analyzing Tampa's anti-SOCE ordinance ${ }^{172}$ - simply begins to scratch the surface.

For instance, some view Becerra as outright overruling Pickup and King. In the Ninth Circuit's January 2019 decision in American Beverage Association v. City and County of San Francisco, ${ }^{173}$ Judge Sandra Ikuta expressed this position in her concurrence. ${ }^{174}$ Others, including U.S. District Judge Paul Grimm in his opinion that same month in Washington Post v. McManus, ${ }^{175}$ view Becerra as signaling that any precedents prior to the Supreme Court's 2015 ruling in Reed v. Town of Gilbert ${ }^{176}$ that accorded "diminished First

168. See supra notes $157,159-61$ and accompanying text.

169. See supra notes $158,142-44$ and accompanying text.

170. See supra notes $16-31,44-45$ and accompanying text.

171. See supra notes 33-41, 46 and accompanying text.

172. Supra note 37 and accompanying text.

173. 916 F.3d 749 (9th Cir. 2019).

174. See id. at 759 (contending that Becerra "overruled our opinion in Pickup v. Brown, 740 F.3d 1208 (9th Cir. 2014), as well as a line of decisions in the Third and Fourth Circuits, see, e.g., King v. Governor of N.J., 767 F.3d 216 (3d Cir. 2014); Moore-King v. Cty. of Chesterfield, 708 F.3d 560 (4th Cir. 2013)").

175. 355 F. Supp. 3d 272 (D. Md. 2019).

176. 135 S. Ct. 2218 (2015). As in Becerra, Justice Thomas authored the opinion of the Court in Reed. Id. at 2224. Thomas wrote in Reed: "Content-based laws- those that target speech based on its communicative content - are presumptively unconstitutional and may be justified only if the government proves that they are narrowly tailored to serve compelling state interests." Id. at 2226 . In 
[Vol. 47: 1, 2019] Amendment protection to certain categories of speech ought to be read nar-
rowly."177

And what about Pickup itself? In November 2018, the Ninth Circuitfive months after the Supreme Court ruled in Becerra-refused to recall its prior mandate ${ }^{178}$ upholding California's anti-SOCE law. ${ }^{179}$ The next month, the Ninth Circuit refused to rehear the case en banc. ${ }^{180}$ Conversion therapist David Pickup and his fellow litigants, with the assistance of Liberty Counsel, ${ }^{181}$ then petitioned the Supreme Court for a writ of certiorari in March

other words, content-based laws must satisfy strict scrutiny. Id. at 2226-27. He added that if a regulation is content based on its face, then there is "no need to consider the government's justifications or purposes for enacting" it, as it must face strict scrutiny. Id. at 2227.

177. McManus, 355 F. Supp. 3d at 297.

178. See Steven D. McLamb, Federal Appellate Procedure-Recall of Mandate-Review of Judgments after Rehearing and Appeal Periods Expire, 24 VILL. L. REV. 157, 159 (1978) ("The mandate is the command of the appellate court to the court below to execute the appellate judgment."); see also FED. R. APP. P. 41 (describing the contents of mandates issued by federal appellate courts).

179. Pickup v. Brown, 2018 U.S. App. LEXIS 31414 (9th Cir. Nov. 6, 2018). Federal appellate courts have inherent discretionary power to recall their mandates to lower courts "in extraordinary circumstances." Calderon v. Thompson, 523 U.S. 538, 549-50 (1998). The Ninth Circuit, for example, holds: "When a decision of the Supreme Court 'departs in some pivotal aspects' from a decision of a federal appeals court, recall of a mandate may be warranted to the extent necessary "to protect the integrity' of the court of appeals' prior judgment." Zipfel v. Halliburton Co., 861 F.2d 565, 567 (9th Cir. 1988) (quoting Am. Iron \& Steel Inst. v. EPA, 560 F.2d 589, 596 (3d Cir. 1977)); see also AaronAndrew P. Bruhl, The Supreme Court's Controversial GVRs-and an Alternative, 107 MICH. L. REV. $711,738 \mathrm{n} .109$ (2009) (asserting that "[r]ecalling the appellate court's mandate is an extraordinary procedure," and contending that "it might occasionally be used to bring a recent decision into conformity with new precedent, especially where the erroneous decision has a continuing prospective effect"); Deborah Roy, Note, The Sixth Circuit's Unprecedented Reopening of Demjanjuk v. Petrovsky, 42 CLEV. ST. L. REV. 737, 745 (1994) (noting that one of the circumstances in which an appellate court may recall a mandate is "when a Supreme Court decision has changed the controlling law").

The power of an appellate court "to recall its mandate is not conferred by statute, but its existence cannot be questioned." Aerojet-General Corp. v. Am. Arbitration Ass'n, 478 F.2d 248, 254 (9th Cir. 1973).

180. See Pickup v. Brown, 2018 U.S. App. LEXIS 36317 (9th Cir. Dec. 21, 2018).

181. The organization describes itself on its website as:

[We are] a Christian ministry that proclaims, advocates, supports, advances, and defends the good news that God in the person of Jesus Christ paid the penalty for our sins and offers forgiveness and eternal life to all who accept him as Lord and Savior. Every ministry and project of Liberty Counsel centers around and is based upon this good news, which is also referred to as the gospel.

About Liberty Counsel, LIBERTY COUNSEL, https://lc.org/about. 
[Vol. 47: 1, 2019]

Testing the First Amendment

PePPERDine LaW REVIEW

2019. ${ }^{182}$

The petition contended that the Supreme Court's decision in Becerra "rejected the Ninth Circuit's newly minted 'professional' speech category, and by name, abrogated Pickup, the case at bar." 183 It added that the Ninth Circuit abused its discretion in late 2018 by refusing to recall its earlier mandate in Pickup "despite this Court's explicit abrogation of its decision and the continuing irreparable injury occurring as a result of the content-based speech restrictions." 184 The petition emphasized that the Ninth Circuit's prior judgment in Pickup regarding professional speech "was not merely questioned, but abrogated by name by this Court, yet the mandate was not recalled." 185 On May 20, 2019, however, the Supreme Court denied the petition, thus leaving intact the Ninth Circuit's 2014 amended opinion in Pickup v. Brown applying only rational basis review to test the constitutionality of an anti-SOCE law. ${ }^{186}$

The Supreme Court's refusal to hear Pickup, however, was thoroughly unsurprising. That is because in April 2019, the Court had denied a petition for a writ of certiorari to review the Third Circuit's decision in King. ${ }^{187}$ It marked the third time that the nation's high court had snubbed consideration of New Jersey's anti-SOCE statute. ${ }^{188}$ In declining to review King, the Supreme Court left in place the Third Circuit's decision applying intermediate scrutiny to the Garden State's anti-SOCE statute. ${ }^{189}$

Liberty Counsel, which represents the conversion therapists challenging the statute in King and other cases, issued a press release in April 2019 stating

182. Pickup v. Brown, 2018 U.S. App. LEXIS 36317 (9th Cir. Dec. 21, 2018), cert. denied, Pickup v. Newsom, 139 S. Ct. 2622 (2019).

183. Petition for Writ of Certiorari at 2, Pickup v. Newsom, 139 S. Ct. 2622 (2019) (No. 18-1244).

184. Id. at 9 .

185. Id. at 12 .

186. See Pickup v. Newsom, 139 S. Ct. 2622 (2019).

187. See King v. Murphy, 139 S. Ct. 1567 (2019).

188. Nancy Cutler, New Jersey Conversion Therapy Ban Stands, for Now, but LGBT Groups Expect More Challenges, LOHUD (Apr. 19, 2019, 4:41 PM), https://www.lohud.com/story/news/new-jersey/2019/04/19/lgbt-groups-new-jersey-new-york-supreme-court-conversion-therapybans/3501891002/.

189. See King v. Governor of N.J., 767 F.3d 216, 234 (3d Cir. 2014) ("We believe that commercial and professional speech share important qualities and, thus, that intermediate scrutiny is the appropriate standard of review for prohibitions aimed at either category."). 
that it "will now refile the case in light of the Supreme Court's express rejection [in Becerra] of the lower court's past ruling which upheld the counseling ban." 190 The press release also laid out the belief of the organization's chairman, Matthew Staver:

It is not a question of if, but when, the Supreme Court will take one of these cases and implement what it already clearly stated-that these laws violate the First Amendment. The fundamental rights of counselors and clients to exercise their right to speak in private counseling sessions must be protected. ${ }^{191}$

Similarly, Liberty Counsel vowed in May 2019 to refile its Pickup case challenging California's anti-SOCE statute. ${ }^{192}$ In a press release, the organization said it intends to "work this case back up to the U.S. Supreme Court." 193 In that press release, Staver called California's law "a gross intrusion into the fundamental rights of counselors and clients." 194

In brief, new laws are being passed in 2019 targeting SOCE on minors ${ }^{195}$ and, in turn, lawsuits attacking those measures will continue to be filed and litigated by organizations such as Liberty Counsel. Cases such as Otto and Vazzo, addressed in the Introduction, bring into sharp relief the difficulties lower courts now face when deciding the level of scrutiny that applies for addressing First Amendment-based speech arguments in those disputes. ${ }^{196}$ Should it be strict scrutiny because the laws, on their face, single out a particular topic - namely, SOCE - for regulation and therefore are content-based measures? ${ }^{197}$ The Supreme Court's 2018 ruling in Becerra, with its attack on

190. NJ Counseling Case Goes Back to Lower Court, LiBERTy COUNSEL (Apr. 15, 2019), https://www.lc.org/newsroom/details/041519-nj-counseling-case-goes-back-to-lower-court.

191. Id.

192. CA Counseling Case Will Return to Lower Court, LIBERTY COUNSEL (May 20, 2019), https://www.lc.org/newsroom/details/052019-ca-counseling-case-will-return-to-lower-court.

193. Id.

194. Id.

195. See supra note 9 and accompanying text.

196. See supra notes 1-45 and accompanying text (addressing Otto and Vazzo).

197. See Kozlowski \& Silver, supra note 22, at 194 ("Under existing Supreme Court precedent, content-based laws that target fully protected expression are subjected to strict scrutiny."). 
a nascent professional speech doctrine, casts serious doubt on whether any lesser standard should apply. ${ }^{198}$ Yet, the Court, by denying petitions in 2019 for writs of certiorari in King ${ }^{199}$ and Pickup, ${ }^{200}$ left in place rulings by the Third and Ninth Circuits that, respectively, applied intermediate scrutiny ${ }^{201}$ and rational basis review. ${ }^{202}$ The next Part contends that Justice Stephen Breyer's favored proportionality approach provides a path forward when analyzing anti-SOCE laws. ${ }^{203}$

\section{A Proportionality APPROACH to ANTI-SOCE StATUteS: AN INSTANCE WHERE FLEXIBILITY IS PARAMOUNT}

This Article so far has demonstrated that courts are divided over scrutiny in anti-SOCE law cases brought by conversion therapists, with the Supreme Court's June 2018 ruling in Becerra compounding the confusion. ${ }^{204}$ Some lower courts believe strict scrutiny applies (Magistrate Sansone in Vazzo), ${ }^{205}$ some believe intermediate scrutiny is appropriate (the Third Circuit in King) ${ }^{206}$ and some find rational basis review provides the correct standard (the Ninth Circuit in Pickup). ${ }^{207}$

Rather than trying to shoehorn anti-SOCE statutes into a traditional approach to First Amendment scrutiny, especially given disagreements ad-

\footnotetext{
198. See supra notes 169-70 and accompanying text (addressing Becerra).

199. King v. Murphy, 139 S. Ct. 1567 (2019).

200. Pickup v. Newsom, 139 S. Ct. 2622 (2019).

201. See King v. Governor of N.J., 767 F.3d 216, 234 (3d Cir. 2014) ("We believe that commercial and professional speech share important qualities and, thus, that intermediate scrutiny is the appropriate standard of review for prohibitions aimed at either category.").

202. See Pickup v. Brown, 740 F.3d 1208, 1231 (9th Cir. 2014) (concluding that California's antiSOCE law "is subject to only rational basis review and must be upheld if it bears a rational relationship to a legitimate state interest").

203. See Jamal Greene, The Supreme Court 2017 Term: Foreword: Rights as Trumps?, 132 HARV. L. REV. 28, 55 (2018) ("Proportionality and balancing approaches to rights have long found favor with Justice Breyer."); discussion infra Part IV.

204. See supra notes 39-42 and accompanying text.

205. See supra notes 33-38 and accompanying text.

206. King, 767 F.3d at 234.

207. Pickup, 740 F.3d at 1231.
} 
dressed earlier over foundational issues such as whether speech is even involved, ${ }^{208}$ Justice Breyer's proportionality tack offers a possibly promising solution. Indeed, the nominee of former President Bill Clinton ${ }^{209}$ has "periodically called for an alternative to strict scrutiny triggered by facially content-based regulations" 210 - an alternative requiring that any "interference with speech must be in proportion to the interests served."211

For Breyer, the Court's traditional tiers of scrutiny - strict, intermediate and rational basis - are merely "guidelines informing [the Court's] approach to the case at hand, not tests to be mechanically applied."212 Similarly, Breyer believes that ferreting out whether a statute regulates speech or conductsomething that both the Third Circuit in King and the Ninth Circuit in Pickup grappled with when considering anti-SOCE statutes - is often an unproductive exercise. ${ }^{213}$ It thus is not surprising, given his casting aside of traditional levels of scrutiny and his disdain for a pure speech-conduct dichotomy, that Breyer's methodology has been described as "a sweeping departure from settled First Amendment doctrine and practice." 214

His version of proportionality, a doctrine firmly entrenched in European law, ${ }^{215}$ focuses on the consequences of laws and may be empirically driven to

208. As noted earlier, the Ninth Circuit concluded that SOCE constitutes conduct, not speech. See supra note 71 and accompanying text.

209. See Current Members, SUP. CT. OF THE U.S., https://www.supremecourt.gov/about/biographies.aspx ("President Clinton nominated him as an Associate Justice of the Supreme Court, and he took his seat August 3, 1994.").

210. Carmen Maye, Public-College Student-Athletes and Game-Time Anthem Protests: Is There a Need for a Constitutional-Analytical Audible?, 24 COMM. L. \& POL'Y 55, 90 (2019).

211. Id. at 89 .

212. Williams-Yulee v. Fla. Bar, 135 S. Ct. 1656, 1673 (2015) (Breyer, J., concurring).

213. See Expressions Hair Design v. Schneiderman, 137 S. Ct. 1144, 1152 (2017) (Breyer, J., concurring). Breyer contends that "because virtually all government regulation affects speech . . . it is often wiser not to try to distinguish between 'speech' and 'conduct,"' especially when the government regulates "human relations." Id. More recently, Breyer observed that "much, perhaps most, human behavior takes place through speech." Nat'l Inst. of Family \& Life Advocates v. Becerra, 138 S. Ct. 2361, 2380 (Breyer, J., dissenting).

214. Lillian R. BeVier, The First Amendment on the Tracks: Should Justice Breyer be at the Switch?, 89 MiNN. L. REV. 1280, 1283 (2005).

215. As one scholar encapsulates it:

"Proportionality" is today accepted as a general principle of law by constitutional courts and international tribunals around the world. "Proportionality review," a structured form 
[Vol. 47: 1, 2019]

determine if a sufficient justification exists for curtailing a right. ${ }^{216}$ In brief, the key question under a Breyer proportionality approach distills to this:

Is the injury done by a statute to a constitutional right such as freedom of expression-more specifically, the negative consequences to the purposes and core values served by protecting speech under the First Amendment ${ }^{217}$ - disproportionate to the beneficial outcomes brought by the statute in serving the government's purported regulatory interest? ${ }^{218}$

of doctrine, now flows across national lines, a seemingly common methodology for evaluating many constitutional and human rights claims. The United States is often viewed as an outlier in this transnational embrace of proportionality in constitutional law.

Vicki C. Jackson, Constitutional Law in an Age of Proportionality, 124 YALE L.J. 3094, 3096 (2015) (footnotes omitted); see also Moshe Cohen-Eliya \& Iddo Porat, The Hidden Foreign Law Debate in Heller: The Proportionality Approach in American Constitutional Law, 46 SAN DIEGo L. REV. 367, 380 (2009) (observing "the well-known European doctrine of proportionality").

216. Mark S. Kende, The Unmasking of Balancing and Proportionality Review in U.S. Constitutional Law, 25 CARDOZO J. INT’L \& COMP. L. 417, 426-27 (2017).

217. Breyer has written that his methodology "places considerable weight upon consequencesconsequences valued in terms of basic constitutional purposes." Stephen Breyer, Madison Lecture: Our Democratic Constitution, 77 N.Y.U. L. REV. 245, 246-47 (2002). When it comes to the First Amendment, the basic constitutional purpose of that provision pivots on helping "to sustain the democratic process both by encouraging the exchange of ideas needed to make sound electoral decisions and by encouraging an exchange of views among ordinary citizens necessary to their informed participation in the electoral process. It thereby helps to maintain a form of government open to participation." Id. at 253

218. The roots of this question are grounded in Breyer's observations in multiple cases. See, e.g., United States v. Alvarez, 567 U.S. 709, 730, 739 (2012) (Breyer, J., concurring) (noting that the Court ultimately must "determine whether the statute works speech-related harm that is out of proportion to its justifications," and concluding that the Stolen Valor Act of 2005 "works disproportionate constitutional harm"); Sorrell v. IMS Health Inc., 564 U.S. 552, 582 (2011) (Breyer, J., dissenting) ("In this case I would ask whether Vermont's regulatory provisions work harm to First Amendment interests that is disproportionate to their furtherance of legitimate regulatory objectives."); Pleasant Grove City v. Summum, 555 U.S. 460, 484 (2009) (Breyer, J., concurring) (contending that "it helps to ask whether a government action burdens speech disproportionately in light of the action's tendency to further a legitimate government objective"); District of Columbia v. Heller, 554 U.S. 570, 689-90 (2008) (Breyer, J., dissenting) (contending, in the context of a Second Amendment case, that "the Court generally asks whether the statute burdens a protected interest in a way or to an extent that is out of proportion to the statute's salutary effects upon other important governmental interests"); Bartnicki v. Vopper, 532 U.S. 514, 536 (2001) (Breyer, J., concurring) (opining that he "would ask whether 
It is an approach that, as Breyer recently wrote in Reed v. Town of Gilbert, ${ }^{219}$ requires "greater judicial sensitivity both to the Amendment's expressive objectives and to the public's legitimate need for regulation" 220 than is captured by bandying about and applying terms such as strict scrutiny. ${ }^{221}$ In other words, one must balance the detrimental consequences, if any, to the objectives of the First Amendment—or, to use Breyer's phrase from his dissent in Becerra - to "the true value of protecting freedom of speech" 22 against the benefits of regulating the speech. ${ }^{223}$

Breyer made clear in Making Our Democracy Work: A Judge's View ${ }^{224}$ that "[p]roportionality involves balancing." 225 Breyer added that proportionality "is specially designed for a context where important constitutional rights and interests conflict" ${ }^{226}$ and "is useful when a statute restricts one constitutionally protected interest in order to further some other comparably important interest." ${ }^{227}$ If one views safeguarding free speech and protecting minors from

the statutes strike a reasonable balance between their speech-restricting and speech-enhancing consequences," and adding that this involves considering whether the restrictions on speech "are disproportionate when measured against their corresponding privacy and speech-related benefits, taking into account the kind, the importance, and the extent of these benefits, as well as the need for the restrictions in order to secure those benefits").

219. 135 S. Ct. 2218 (2015) (Breyer, J., concurring).

220. Id. at 2234 .

221. Id. Breyer articulated his preferred methodology nearly twenty years ago:

[W] here a law significantly implicates competing constitutionally protected interests in complex ways[,] the Court has closely scrutinized the statute's impact on those interests . . but refrained from employing a simple test that effectively presumes unconstitutionality. Rather, it has balanced interests. And in practice that has meant asking whether the statute burdens any one such interest in a manner out of proportion to the statute's salutary effects upon the others (perhaps, but not necessarily, because of the existence of a clearly superior, less restrictive alternative).

Nixon v. Shrink Mo. Gov't PAC, 528 U.S. 377, 402 (2000) (Breyer, J., concurring).

222. Nat'l Inst. of Family \& Life Advocates v. Becerra, 138 S. Ct. 2361, 2383 (2018) (Breyer, J., dissenting).

223. Nixon, 528 U.S. at 402.

224. STEPHEN BREYer, MAKING OUR DEMOCRACY WORK: A JUdGE’S VIEW (2010).

225. Id. at 164 .

226. Id. at $163-64$.

227. Id. at 163 . 
harm as comparably important interests, then proportionality provides a vehicle for analyzing anti-SOCE statutes, which restrict the speech of counselors in the name of shielding minors from injuries conversion therapy allegedly causes. 228

How, then, might a proportionality analysis of a statute banning SOCE on minors play out in court? One possibility unspools as follows: initially and at the macro level, a judge must consider whether the harm caused by such a statute to the core purposes of protecting speech under the First Amendment ${ }^{229}$ is disproportionate to the benefits of protecting minors from SOCE. ${ }^{230}$ In other words, are the deleterious consequences of an anti-SOCE statute to core First Amendment values (core values, at least, for Justice Breyer) - facilitating "the processes through which political discourse or public opinion is formed or expressed," 231 enabling democratic self-governance ${ }^{232}$ and "maintaining a free marketplace of ideas" ${ }^{n 33}$ — disproportionate to the demonstrable

228. Id. at $163-64$.

229. See Breyer, supra note 217, at 246-47 (describing his approach as placing "considerable weight upon consequences-consequences valued in terms of basic constitutional purposes") (emphasis added).

230. See King v. Governor of N.J., 767 F.3d 216, 240 (3d Cir. 2014) (noting that minors are more vulnerable to SOCE).

231. Expressions Hair Design v. Schneiderman, 137 S. Ct. 1144, 1152 (2017) (Breyer, J., concurring) (identifying these as "interests close to the First Amendment's protective core").

232. Justice Breyer explains this core value of protecting expression:

The First Amendment in context forms a necessary part of a constitutional system designed to sustain that democratic self-government. The Amendment helps to sustain the democratic process both by encouraging the exchange of ideas needed to make sound electoral decisions and by encouraging an exchange of views among ordinary citizens necessary to their informed participation in the electoral process. It thereby helps to maintain a form of government open to participation (in Constant's words, by "all the citizens, without exception").

Breyer, supra note 217 , at 252-53..

233. Sorrell v. IMS Health Inc., 564 U.S. 552, 583 (2011) (Breyer, J., dissenting). Of particular importance regarding the constitutionality of anti-SOCE statutes, Justice Breyer distinguishes between a free marketplace of ideas and a "free marketplace for goods and services," with the latter receiving "considerably less protection" under the First Amendment. Id. (emphasis added). To the extent that SOCE are performed as a service to patients, this suggests that core First Amendment values are not implicated by anti-SOCE statutes. Id. at 582; see also King, 767 F.3d at 237 (explaining that the antiSOCE statutes do not implicate the First Amendment as heavily because of the nature of the therapist's role in providing a service to clients). 
and beneficial consequences to minors of not being subjected to the speech that comprises SOCE?

On the consequences-to-speech side of this equation, a judge would need to consider that the First Amendment speech rights of therapists are affected by anti-SOCE laws only within the narrow context and confines of a therapistclient relationship. ${ }^{234}$ For Justice Breyer, this is important because he draws a crucial line between protecting speech that facilitates a diverse marketplace of ideas (a core First Amendment value) and protecting speech that enables a marketplace of goods and services (not core First Amendment values). ${ }^{235}$

The only expression restricted by anti-SOCE laws falls within the scope of private services rendered by conversion therapists with minor patients. ${ }^{236}$ In other words, the lone speech banned takes the form of a service performed on minors that is designed to change their sexual orientation. ${ }^{237}$ It does not take the form of speech propounding ideas that are intended to change a minor's political or religious views and beliefs about homosexuality. ${ }^{238}$ Additionally, no speech is restricted by anti-SOCE statutes in the public marketplace of ideas concerning whether conversion therapy is a good idea or a harmful practice or, in turn, whether it should be regulated by state or local governmental entities, or both. ${ }^{239}$ Conversion therapists and others who believe in the efficacy of SOCE are free to publicly speak their minds about this in any and all public fora.

234. See Pickup v. Brown, 740 F.3d 1208, 1228 (9th Cir. 2014) (discussing the First Amendment implications on the rights of therapists within the scope of their professional relationship with clients). 235. See supra note 233.

236. See Clay Calvert et al., Conversion Therapy and Free Speech: A Doctrinal and Theoretical First Amendment Analysis, 20 WM. \& MARY J. WOMEN \& L. 525, 541 (2014) (explaining that the California anti-SOCE law only bans "counseling designed to thwart or change a minor's exploration of his or her sexual orientation"); see also Conversion Therapy Laws, LGBT MOVEMENT ADVANCEMENT PROJECT (Aug. 5, 2019), https://www.lgbtmap.org/img/maps/citations-conversiontherapy.pdf (demonstrating that a number of states ban conversion therapy of minor patients).

237. See Calvert et al., supra note 262, at 541.

238. See supra note 21 and accompanying text.

239. See supra note 233 and accompanying text; see also King v. Governor of N.J., 767 F.3d 216, 237 (3d Cir. 2014) (explaining that a particular New Jersey anti-SOCE statute still allows conversion therapists to express their viewpoints publicly). 
This is important because it means that speech affecting the political process regarding whether conversion therapy should be regulated by the government-including lobbying both for and against candidates for public office based on their positions regarding SOCE regulation - is not impeded by antiSOCE statutes. In brief, core First Amendment values appear not to be squelched by anti-SOCE laws. Instead, only speech performed as a rendering of services in a private, one-on-one setting with the goal of changing a person's sexual orientation is detrimentally impacted.

In a nutshell, anti-SOCE statutes regulate speech only within the confines of a private setting - a therapist's office, behind closed doors. A therapist's speech in public settings - in newspaper opinion columns, during television interviews and at town hall meetings - about SOCE is not restrained in any manner by anti-SOCE statutes like those now at issue in $\operatorname{Vazzo}^{240}$ and Otto. ${ }^{241}$

That, however, is only half of the proportionality equation (namely, the consequences to core First Amendment speech values wrought by anti-SOCE statutes). What about the consequences to minors - the alleged benefits to them of restraining speech and not being subjected to SOCE? ${ }^{242}$

A key issue here is whether a governmental entity seeking to ban SOCE can, in fact, demonstrate tangible benefits to minors of squelching conversion therapists' speech that occurs in the setting of therapist-client relationships. ${ }^{243}$ This may not be an easy task because, under the Supreme Court's strict scrutiny test, the government must demonstrate "a direct causal link between the restriction imposed and the injury to be prevented" 244 such that "the Government's chosen restriction on the speech at issue [is] 'actually necessary' to achieve its interest." ${ }^{245}$ Deploying this direct-causal-link requirement, the Court holds that "ambiguous proof will not suffice." ${ }^{246}$ Similarly, evidence of

240. See supra notes 33-42 and accompanying text.

241. See supra notes $1-5$ and accompanying text.

242. See King, 767 F.3d at 238 (explaining that minors could face "serious health risks" as a result of SOCE).

243. Id. at 221-22 (discussing studies cited by the New Jersey legislature that emphasize the ineffectiveness of, and risks associated with, SOCE).

244. United States v. Alvarez, 567 U.S. 709, 725 (2012) (emphasis added).

245. Id.

246. Brown v. Entm't Merchs. Ass'n, 564 U.S. 786, 799-800 (2011). 
a correlation - rather than causation - between the restricted speech and the harm it allegedly causes is not sufficient to surmount this hurdle. ${ }^{247}$ In brief, "under strict scrutiny, the government must unambiguously prove the existence of an actual problem directly caused by regulated speech." 248

Applying such an approach for determining the impact of speech, governmental entities regulating SOCE seemingly would need to point to empirical studies demonstrating actual causation of harm to minors who undergo SOCE. ${ }^{249}$ Proving that SOCE may not work - that it is ineffective quackerymay be one thing, but proving that it actually causes harm is quite another. There is, in other words, a difference between inefficacy and harmfulness.

Courts thus would need to examine experimental research — not simply anecdotal accounts and occasional incidents - to resolve this issue. The APA task force report noted earlier ${ }^{250}$ would need to be closely scrutinized. ${ }^{251}$ It was written in 2009, however, so the results of any and all SOCE-based experiments conducted during the past decade would need to be analyzed as well. ${ }^{252}$

Yet, all of the above rigor regarding direct proof of causation assumes a strict scrutiny approach like that recently adopted by the Supreme Court in both Brown v. Entertainment Merchants Ass' $n^{253}$ and United States v. Alvarez. ${ }^{254}$ How might Justice Breyer, in contrast, consider evidence of alleged harms under his proportionality tack? In fact, Breyer's dissent in Brown provides a window on his thinking that illustrates a very different understanding of what it takes to demonstrate a speech-based injury sufficient to warrant

\footnotetext{
247. Id.

248. Clay Calvert \& Matthew D. Bunker, An "Actual Problem" in First Amendment Jurisprudence? Examining the Immediate Impact of Brown's Proof-of-Causation Doctrine on Free Speech and Its Compatibility with the Marketplace Theory, 35 HASTINGS COMM. \& ENT. L.J. 391, 396 (2013). 249. See id. (explaining that the government must provide strong evidence supporting its compelling state interest under the strict scrutiny test).

250. See supra note 10 and accompanying text.

251. See Calvert et al., supra note 236, at 532-33 (highlighting the emphasis a California District Court Judge placed on evaluating California's scientific evidence of the causation of SOCE's potential harm to minors).

252. See supra note 10 and accompanying text.

253. 564 U.S. 786 (2011).

254. 567 U.S. 709 (2012).
} 
regulation. ${ }^{255}$

Brown centered on whether a California statute that restricted minors' access to violent video games violated the First Amendment. ${ }^{256}$ The Court, in an opinion authored by Justice Antonin Scalia, applied strict scrutiny ${ }^{257}$ and declared the law unconstitutional. ${ }^{258}$ A fatal flaw for California, according to the majority, was that it failed to "show a direct causal link between violent video games and harm to minors." 259 Justice Scalia observed that the only thing California could establish with the social science studies it offered into evidence was a possible correlation, not causation, between violent content and aggression. ${ }^{260}$ Justice Scalia added that any real-world effects suggested by the studies were, in fact, "minuscule"261 and "indistinguishable from effects produced by other media." 262 In brief, the majority scoffed at the evidence of harm California proffered.

Justice Breyer, however, disagreed with this interpretation of the evidence and wrote a dissent. ${ }^{263}$ Of particular importance, Justice Breyer gave great weight and deference to the view of multiple learned organizations that concluded there was "a significant risk that violent video games, when compared with more passive media, are particularly likely to cause children harm." ${ }^{264}$ One of those organizations, he pointed out, was the American Psychological Association. ${ }^{265}$ The APA, of course, is the same entity cited earlier ${ }^{266}$ that released a 2009 task force report concluding that sexual orientation change

255. See Brown, 564 U.S. at 847 (Breyer, J., dissenting).

256. Id. at 788 .

257. See id. at 799 ("Because the Act imposes a restriction on the content of protected speech, it is invalid unless California can demonstrate that it passes strict scrutiny, i.e., it is justified by a compelling government interest and is narrowly drawn to serve that interest.").

258. See id. at 805 ("Legislation such as this, which is neither fish nor fowl, cannot survive strict scrutiny.").

259. Id. at 799 .

260. Id. at 800 .

261. Id.

262. Id. at $800-01$.

263. Id. at $839-57$.

264. Id. at 853 .

265. Id.

266. Supra note 10 and accompanying text. 
efforts "are unlikely to be successful and involve some risk of harm."267 In brief, Justice Breyer gives credence to the views of an organization whose report on SOCE plays a key role in supporting laws that target it. ${ }^{268}$

In Brown, Justice Breyer willingly deferred to the judgment of California lawmakers in relying on comprehensive reviews of the evidence by organizations such as the APA about the effects of violent video games on minors. ${ }^{269}$ He emphasized that Justice Scalia and the majority failed to grant such deference. ${ }^{270}$ Deference is owed to lawmakers, Justice Breyer asserted, when the Justices lack expertise on "technical matters." 271 Social science is precisely such an area, Breyer contended. ${ }^{272}$

Finally, Breyer's dissent in Brown reveals his willingness to tolerate a certain amount of ambiguity and disagreement regarding the findings of specific social science studies. As he put it, "[1]ike many, perhaps most, studies of human behavior, each study has its critics, and some of those critics have produced studies of their own in which they reach different conclusions."273 What was seemingly pivotal in Brown for Breyer was that despite such disagreements about individual studies, organizations like the APA that reviewed the entire body of evidence concluded that violent content creates a significant risk of harm to minors. ${ }^{274}$

267. Am. Psychol. Ass'n, RePORT OF THE AMERICAN PSyCHOLOGICAL ASSOCIATION TASK ForCE ON APPROPRiate Therapeutic Responses to SEXUAL Orientation, at $\mathrm{v}$ (2009), https://www.apa.org/pi/lgbt/resources/therapeutic-response.pdf.

268. See Brown, 564 U.S. at 855 (Breyer, J., dissenting) (finding weight in the APA's research on the effects of video games on adolescents).

269. Id. ("Unlike the majority, I would find sufficient grounds in these studies and expert opinions for this Court to defer to an elected legislature's conclusion that the video games in question are particularly likely to harm children.").

270. Id.

271. Id.

272. See id. at 853 ("I, like most judges, lack the social science expertise to say definitively who is right.").

273. Id.

274. Id. at 853-55. As Justice Breyer put it:

I, like most judges, lack the social science expertise to say definitively who is right. But associations of public health professionals who do possess that expertise have reviewed many of these studies and found a significant risk that violent video games, when compared with more passive media, are particularly likely to cause children harm. 
In a nutshell, Breyer's approach to social science evidence pivots on deference and, in particular, deference granted both to professional organizations that address health and safety issues and to lawmakers that rely on the reports of those organizations. ${ }^{275}$ Therefore, when lawmakers rely on reports by organizations such as the APA when adopting anti-SOCE statutes, Breyer would seem likely to grant them deference in their determination that conversion therapy harms minors. ${ }^{276}$ This, in turn, makes the odds of upholding an antiSOCE statute much greater than the direct-causal-link approach used by the Court under a strict scrutiny standard. ${ }^{277}$

Finally, Breyer's approach here may be useful because of the difficulty of conducting experimental studies involving SOCE on minors. Specifically, it seems highly unlikely that a university's institutional review board would approve a study on minors that might, in fact, genuinely harm them regarding something as core to their being as sexual orientation. ${ }^{278}$ Even Justice Scalia acknowledged, when considering the alleged effects of broadcast profanity on minors, that " $[t]$ here are some propositions for which scant empirical evidence

Id. at 853 .

275. Clay Calvert et al., Social Science, Media Effects \& the Supreme Court: Is Communication Research Relevant After Brown v. Entertainment Merchants Association?, 19 UCLA ENT. L. REV. 293, 305 (2012).

276. See id. at 305-06 (describing how Justice Breyer would generally defer to expert opinions regarding topics on which Breyer is not an expert); see also Brown, 564 U.S. at 855 (Breyer, J., dissenting) ("I would find sufficient grounds in these studies and expert opinions for this Court to defer to an elected legislature's conclusion that the video games in question are particularly likely to harm children.").

277. See supra notes 245-49 and accompanying text (describing the requirement for the Court to show a direct causal link between the proffered restriction and the harm the Court wants to prevent in order to comply with a strict scrutiny standard in interpreting anti-SOCE statutes); Brown, 564 U.S. at 853-54 (Breyer, J., dissenting) (giving credence to the American Psychological Association about video games harming children). Since Breyer relies on the APA's views in Brown, it is likely that he would also rely on the APA's views regarding sexual orientation change efforts being harmful and ineffective for children, thereby increasing the odds of upholding anti-SOCE statutes. See id. at 855 . 278. See Ralph L. Rosnow et al., The Institutional Review Board as a Mirror of Scientific and Ethical Standards, 48 AM. PSYCHOL. 821, 822 (1993) (it is "[a] central responsibility of IRBs ... to ensure that the potential benefits to the individual research participants (and to society) will be greater than any risks that may be encountered by participation in the research" (citation omitted)). 
can be marshaled." 279 He explained there that "[o]ne cannot demand a multiyear controlled study, in which some children are intentionally exposed to indecent broadcasts (and insulated from all other indecency), and others are shielded from all indecency." ${ }^{280}$ The same could easily be said about conducting such a study of SOCE where the alleged harm is not merely the expansion of a child's vocabulary to include expletives and naughty language, but much more serious ailments, such as anxiety, depression, and suicidal feelings. ${ }^{281}$

Where, then, does this leave a judge if a proportionality analysis to an anti-SOCE statute were to unfold as laid about above? If, as articulated earlier, a judge finds: (1) that core First Amendment interests in protecting speech - for Breyer, this means promoting a diverse marketplace of ideas (rather than one for services) and facilitating democratic self-governance ${ }^{282}$-are not implicated by regulating speech regarding SOCE that occurs only in the context of a private, one-on-one, therapist-client relationship; and (2) that the views of organizations, such as the APA, about the negative consequences of SOCE on minors are to be given substantial weight and deference, then the next step is for a judge to decide if the harm to First Amendment interests is disproportionate to the positive consequences for minors of being shielded by statute from SOCE. This, in other words, is the comparison of the consequences on both sides of the equation to determine if the good brought by the statute to LGBTQ children outweighs the harm worked to First Amendment interests. ${ }^{283}$ That decision, of course, would be left to a judge, not the musings of a professor in a law journal article. ${ }^{284}$

The hypothetical analysis set forth immediately above under a possible proportionality approach to scrutiny is merely one conceivable scenario, but

279. FCC v. Fox TV Stations, Inc., 556 U.S. 502, 519 (2009).

280. Id.

281. Supra note 11 and accompanying text.

282. See supra notes 231-33 and accompanying text (addressing what Breyer perceives as core reasons why the First Amendment protects speech).

283. See supra notes 217-18 and accompanying text; see also District of Columbia v. Heller, 554 U.S. 570, 693 (2008) (Breyer, J., dissenting) ("The ultimate question is whether the statute imposes burdens that, when viewed in light of the statute's legitimate objectives, are disproportionate.").

284. See United States v. Alvarez, 567 U.S. 709, 730 (2012) (stating that the Court is the one to "determine whether the statute works speech-related harm that is out of proportion to its justifications"). 
it is not the only one. What is more, it hinges partly on the core values of protecting speech under the First Amendment as Justice Breyer seemingly perceives them. ${ }^{285}$ Other justices, however, might focus on different values, such as protecting the right of conversion therapists to realize their own identities through speech as therapists who attempt to change the sexual orientation of gay and lesbian minors. ${ }^{286}$ Adopting such a view seemingly would change the analysis, suggesting a greater harm to First Amendment speech interests when balanced against the positive consequences of shielding minors from SOCE. ${ }^{287}$ Regardless, this Article has gone beyond simply proposing that proportionality might apply, but has illustrated how it might, in fact, be deployed. With courts currently divided all over the tiers-of-scrutiny hierarchy about which traditional standard applies to anti-SOCE laws, Justice Breyer's flexible approach merits a close look.

\section{CONCLUSION}

Sexual orientation change efforts involve a "combustible combination of political, religious, psychiatric, and cultural forces." ${ }^{288}$ The Supreme Court now needs to douse one facet of this flammable concoction by definitively

285. Breyer, supra note 217, at 253 (explaining what Breyer believes to be the core values of protecting First Amendment speech); see also supra notes 231-33 and accompanying text (listing the three core values of protecting speech under the First Amendment).

286. See C. Edwin Baker, Scope of the First Amendment Freedom of Speech, 25 UCLA L. REV. 964, 966 (1978) (contending that speech should be safeguarded not only "as a means to a collective good but because of the value of speech conduct to the individual"). As more fully explained by Professor Edward J. Eberle:

Intrinsically, free speech is valuable because it promotes and reflects human personality and is an essence of human dignity. Autonomy to think, listen, and speak for oneself is essential to a free and self-determining human being. Free speech theorists have captured aspects of this justification for expression as resting on a basis of individual self-fulfillment, self-realization, or liberty.

Edward J. Eberle, Cross Burning, Hate Speech, and Free Speech in America, 36 ARIZ. ST. L.J. 953, 960-61 (2004) (footnotes omitted).

287. Baker, supra note 286, at 966 ("Speech is protected not as a means to a collective good but because of the value of speech conduct to the individual."); $f$. supra note 11 and accompanying text (listing some of the potential negative effects of SOCE, including depression, anxiety, and suicidal thoughts).

288. Calvert \& Bunker, supra note 248 , at 394. 
resolving the standard of scrutiny that applies when conversion therapists bring free-speech challenges to anti-SOCE statutes. Unfortunately, the Court twice dodged opportunities in 2019 to do precisely that by refusing to hear King and Pickup. ${ }^{289}$

This Article illustrated the different approaches lower courts have embraced regarding scrutiny in cases attacking anti-SOCE statutes. ${ }^{290}$ It also demonstrated how the Supreme Court's 2018 decision in Becerra exacerbated problems by condemning a nascent professional speech doctrine. ${ }^{291}$ That doctrine was favorably cited by the Third Circuit in King and the Ninth Circuit in Pickup to justify applying tests-intermediate scrutiny in King ${ }^{292}$ and rational basis review in Pickup ${ }^{293}$ - less than strict scrutiny. Furthermore, the Article revealed disagreement in early 2019 over scrutiny in the Hamilton and Vazzo cases involving anti-SOCE statutes. ${ }^{294}$ In brief, judges are flailing over scrutiny in the aftermath of Becerra. And, unfortunately, this state of disarray arises just as more states are adopting anti-SOCE statutes. ${ }^{295}$

Perhaps most significantly, the Article suggested that Justice Stephen Breyer's proportionality methodology, rather than a traditional level of scrutiny, may provide a solution for resolving the scrutiny debate in anti-SOCE law cases, especially given the disagreement among lower courts over

289. See supra notes 186-87 (noting the Court's refusal to grant a petition for writ of certiorari in both Pickup and King).

290. See supra text accompanying notes 43-46 (describing how federal judges in the same state believed different standards of scrutiny applied to interpretation of anti-SOCE statutes); see, e.g., Otto v. City of Boca Raton, 353 F. Supp. 3d 1237, 1258 (S.D. Fla. 2019) ("The Court concludes that it is unclear what standard of review should apply to this case. It seems likely that the ordinances are subject to more than rational basis review, but beyond the determination, it is unclear whether intermediate or strict scrutiny should apply.”); Vazzo v. City of Tampa, No. 8:17-cv-2896-T-02AAS, 2019 U.S. Dist. LEXIS 35935, at*19 (M.D. Fla. Jan. 30, 2019) (agreeing with the Court in Becerra that "traditional constitutional analyses, including strict-scrutiny analysis, applies to content-based regulations on professional speech").

291. Nat'l Inst. of Family \& Life Advocates v. Becerra, 138 S. Ct. 2361, 2375 (2018) ("[N]either California nor the Ninth Circuit has identified a persuasive reason for treating professional speech as a unique category that is exempt from ordinary First Amendment principles.").

292. See King v. Governor of N.J., 767 F.3d 216, 234 (3d Cir. 2014).

293. See Pickup v. Brown, 740 F.3d 1208, 1231 (9th Cir. 2014).

294. See supra Part I (addressing how the courts in Otto and Vazzo resolved the scrutiny question).

295. See supra note 9. 
[Vol. 47: 1, 2019]

whether speech is even at issue. ${ }^{296}$ The Article also offered one possible scenario for how a proportionality approach might unfold in an anti-SOCE case filed by a conversion therapist. ${ }^{297}$ That scenario, of course, is clearly not the only one a court might adopt; it was simply proposed here to illustrate what a Breyer-like approach might entail.

The bottom line is that the Supreme Court urgently needs to clarify how Becerra affects scrutiny in anti-SOCE law cases. In the process, it must identify the correct level of scrutiny in such disputes. The occupational future of conversion therapists and, more importantly, the psychological wellbeing of minors, rest in the balance.

296. See supra notes 71-85 (explaining how the Ninth Circuit in Pickup concluded that SOCE was merely conduct and therefore California's anti-SOCE statute was subject to mere rational basis review).

297. See supra notes 283-84 and accompanying text (explaining how a Breyer-like approach might play out). 